\title{
DUX4-induced constitutive DNA damage and oxidative stress contribute to aberrant differentiation of myoblasts from FSHD patients
}

\author{
Petr Dmitriev ${ }^{\mathrm{a}, \mathrm{b}, 1}$, Yara Bou Saada ${ }^{\mathrm{a}, 1}$, Carla Dib ${ }^{\mathrm{a}}$, Eugénie Ansseau ${ }^{\mathrm{d}}$, Ana Barat ${ }^{\mathrm{a}}$, \\ Aline Hamade ${ }^{\mathrm{e}}$, Philippe Dessen ${ }^{c}$, Thomas Robert ${ }^{c}$, Vladimir Lazar ${ }^{c}$, Ruy A.N. Louzada ${ }^{g}$, \\ Corinne Dupuy ${ }^{\mathrm{g}}$, Vlada Zakharova ${ }^{\mathrm{f}}$, Gilles Carnac ${ }^{\mathrm{b}}$, Marc Lipinski ${ }^{\mathrm{a}}$, Yegor S. Vassetzky ${ }^{\mathrm{a}, \mathrm{f}, *}$ \\ a UMR 8126, Univ. Paris-Sud, CNRS, Institut de Cancérologie Gustave-Roussy, F-94805 Villejuif, France \\ ${ }^{\mathrm{b}}$ PhyMedExp, University of Montpellier, INSERM U1046, CNRS UMR 9214, F-34295 Montpellier cedex 5, France \\ ${ }^{c}$ Functional Genomics Unit, Institut de Cancérologie Gustave-Roussy, F-94805 Villejuif, France \\ d Laboratory of Molecular Biology, University of Mons, 20 place du Parc, B700 Mons, Belgium \\ e ER030-EDST, Department of Life and Earth Sciences, Faculty of Sciences II, Lebanese University, Lebanon \\ ${ }^{\mathrm{f}}$ Lomonosov Moscow State University, Faculty of Bioengineering and Bioinformatics, 119991 Moscow, Russia \\ g UMR 8200, Univ., Paris-Sud, CNRS, Institut de Cancérologie Gustave-Roussy, F-94805 Villejuif, France
}

Keywords:

Facioscapulohumeral dystrophy

DNA damage

DUX4

Oxidative stress

Antioxidants

\begin{abstract}
A B S T R A C T
Facioscapulohumeral dystrophy (FSHD) is one of the three most common muscular dystrophies in the Western world, however, its etiology remains only partially understood. Here, we provide evidence of constitutive DNA damage in in vitro cultured myoblasts isolated from FSHD patients and demonstrate oxidative DNA damage implication in the differentiation of these cells into phenotypically-aberrant myotubes. Double homeobox 4 (DUX4), the major actor in FSHD pathology induced DNA damage accumulation when overexpressed in normal human myoblasts, and RNAi-mediated DUX4 inhibition reduced the level of DNA damage in FSHD myoblasts. Addition of tempol, a powerful antioxidant, to the culture medium of proliferating DUX4-transfected myoblasts and FSHD myoblasts reduced the level of DNA damage, suggesting that DNA alterations are mainly due to oxidative stress. Antioxidant treatment during the myogenic differentiation of FSHD myoblasts significantly reduced morphological defects in myotube formation. We propose that the induction of DNA damage is a novel function of the DUX4 protein affecting myogenic differentiation of FSHD myoblasts.
\end{abstract}

\section{Introduction}

Facioscapulohumeral dystrophy (FSHD) is an autosomal dominant disease manifesting mainly as wasting of specific groups of facial and limb muscles. The prevalence of FSHD is estimated to be as high as 8 in 100,000 suggesting that it might be the most common muscular dystrophy in the Western world [1]. FSHD has been genetically linked to a shortened macrosatellite repeat array D4Z4, specific polymorphisms and sequence variants on the long arm of chromosome 4 (region 4q35) which together are thought to create a context permissive for aberrant gene expression (reviewed in $[2,3])$.

Every D4Z4 repeat on chromosome $4 \mathrm{q} 35$ contains a promoter

\footnotetext{
* Corresponding author at: UMR 8200, Univ., Paris-Sud, CNRS, Institut de Cancérologie Gustave-Roussy, F-94805 Villejuif, France.

E-mail address: vassetzky@igr.fr (Y.S. Vassetzky).

${ }^{1}$ These authors contributed equally to this work.
}

and a coding region for the DUX4 gene. Several studies have documented a higher level of expression of DUX4 as well as several proximally located genes in FSHD cells and tissues (reviewed in $[2,3]$ ). Transcriptomic and proteomic studies have revealed an abnormal expression of a number of mRNA, microRNAs and proteins in in vitro cultured myoblasts isolated from FSHD patients as compared to healthy controls [4-18].

In vitro cultured FSHD myoblasts which suffer from a defect in the myogenic differentiation program [5], demonstrate a low fusion index and morphological abnormalities when differentiated into myotubes $[18,19]$ and are sensitive to oxidative stress $[19,20]$. In agreement with these observations, it was demonstrated that the expression of oxidative stress-related genes was altered in FSHD cells $[7,8,11,12,20,21]$ and tissues [9,22] suggesting that FSHD cells might be subjected to an endogenous oxidative stress.

Increasing evidence indicates that oxidative stress can reduce the differentiation efficiency of human myoblasts; persistent reactive oxygen species (ROS) act as signaling molecules in several 
physiological processes in human skeletal muscle cells, they are notably known to affect their morphology and function (for review see $[23,24]$ ); both increased mitochondrial production of ROS and NF-kB signaling linked to increased production of ROS can lead to muscle atrophy $[25,26]$.

Several previous observations suggest that increased DUX4 expression might provoke oxidative stress. DUX4, when overexpressed in mouse immortalized myoblasts $\mathrm{C} 2 \mathrm{C} 12$ or human rhabdomyosarcoma cell line RD, altered the expression of genes controlling redox balance and genes involved in the Nrf2-mediated oxidative stress response pathway $[21,27]$. Furthermore, inducible DUX4 overexpression in $\mathrm{C} 2 \mathrm{C} 12$ cells rendered them more sensitive to paraquat, a pro-oxidant compound [27]. However, the increased production of ROS in cells overexpressing DUX4 has never been demonstrated directly.

Oxidative stress is known to induce toxic effects through production of peroxides and free radicals that damage proteins, lipids,

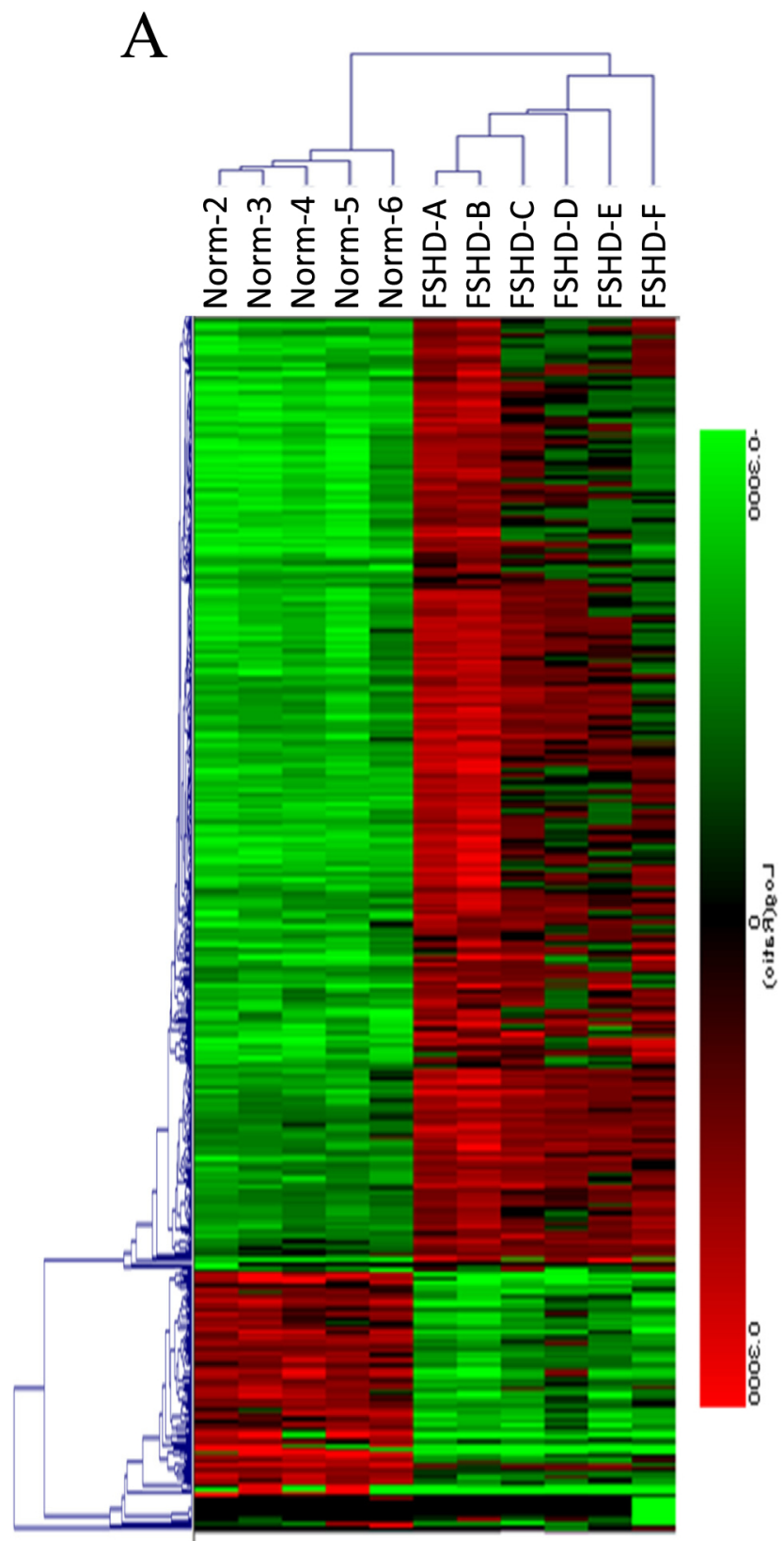

and DNA in the cell. DNA damage and genetic instability are known to be involved in the etiology of many human diseases including cancer, neurodegenerative disorders, and aging (for review see $[28,29]$ ) and were also described in Duchenne (DMD) and Limb-girdle Muscular (LGMD) dystrophies, but not in FSHD [30] (for review see [31]).

Here we describe a novel phenotypic feature of in vitro cultured FSHD myoblasts: a high level of DNA damage lesions, increased production of ROS and upregulation of many genes related to DNA damage repair. Furthermore, we demonstrated for the first time that DUX4 overexpression in human immortalized myoblasts results in a higher level of ROS in these cells. We also demonstrated that DNA damage and increased production of ROS were closely implicated in FSHD pathophysiology and that treatment of FSHD myoblasts with an antioxidant during myogenic differentiation significantly improved the phenotype of resulting FSHD myotubes.

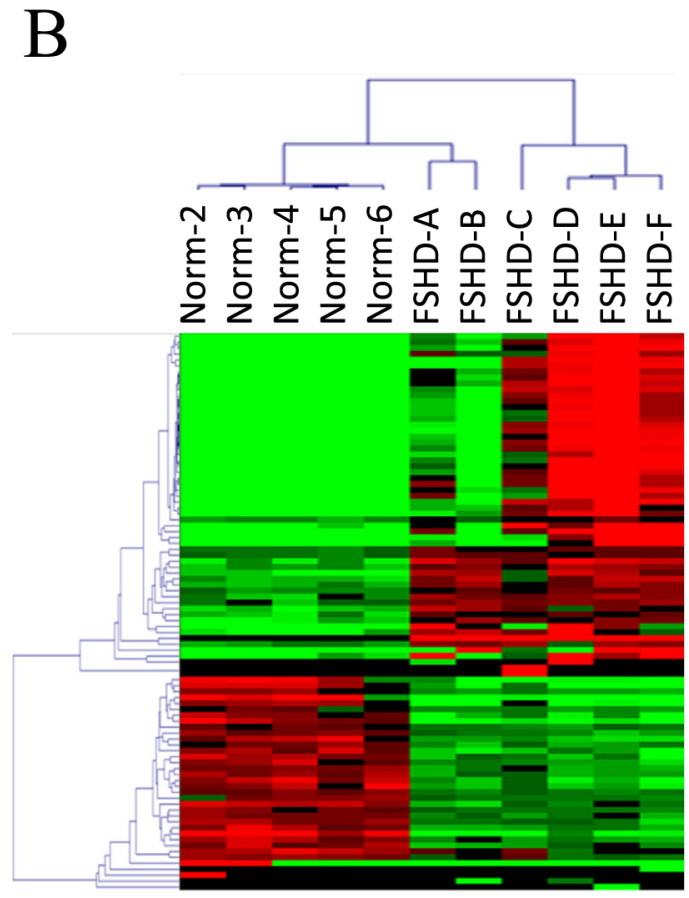

Fig. 1. Supervised clustering of gene expression profiles of in vitro cultured primary myoblasts (A) isolated from five healthy individuals (Norm-2,3,4,6) and six FSHD patients (FSHD-A,B,C,D,E,F) and myotubes derived from these myoblasts (B). 


\section{Results}

\subsection{Transcriptome profiling of FSHD myoblasts}

Several transcriptome analyses of FSHD muscles have been carried out so far, but many of these studies were done either on biopsies or on non-purified myoblasts containing contaminating fibroblasts and adipocytes $[7,10,12]$. To gain insight into mechanisms of FSHD, we have analyzed transcriptional profiles in purified $\mathrm{CD} 6^{+}$myoblasts and myotubes derived from either normal subjects or FSHD patients as described elsewhere [19]. Agilent Human Genome $8 \times 44 \mathrm{~K}$ microarrays were used to identify differentially expressed genes as described in Materials and Methods. Microarray analysis of FSHD myoblasts revealed 312 up- and 88 downregulated protein-coding genes (Fig. 1A), while only 71 and 38 protein-coding genes were respectively up- and downregulated in FSHD myotubes (Fig. 1B) as compared to myoblasts and myotubes isolated from healthy subjects (Table 1, Supplementary Tables S1, S3-6).

The functional annotation of 312 genes upregulated in FSHD myoblasts resulted in 8 superclusters, each integrating several similar Gene Ontology (GO) functional categories (Supplementary Table S2); the three largest superclusters were Regulation of cell cycle, DNA repair and Chromatin organization. Interestingly, 29 genes upregulated in FSHD myoblasts were involved both in cell cycle regulation and DNA damage detection and repair. In total, 54 genes upregulated in proliferating FSHD myoblasts were involved in DNA damage repair (Table 2 and Supplementary Table S4).

Genes downregulated in FSHD myoblasts constituted a unique functional class, Cell adhesion; genes upregulated in FSHD myotubes produced a single marginally significant GO functional category, Cell motility and migration, while no significant functional category could be attributed to the genes downregulated in FSHD myotubes (Table 3 and Supplementary Table S5).

\subsection{DNA damage in FSHD myoblasts}

In order to substantiate the transcriptomic data, we tested the phosphorylation of histone H2A variant $\mathrm{H} 2 \mathrm{AX}$ at Ser-139 ( $\gamma \mathrm{H} 2 \mathrm{AX}$ ), a marker for DNA damage that correlated with the presence of DNA double-stranded breaks (DSB). Using immunoblotting we found that the overall level of $\gamma \mathrm{H} 2 \mathrm{AX}$ in the protein extracts of FSHD myoblasts was significantly higher as compared to normal myoblasts (Fig. 2A and B). Immunofluorescent microscopy revealed a higher percentage of nuclei with $\gamma \mathrm{H} 2 \mathrm{AX}$ foci in FSHD myoblasts than in normal cells (Fig. 2C and D). The observation that a large number of DNA Damage Response (DDR)-related genes were upregulated in FSHD myoblasts and were accompanied by a significantly higher level of $\gamma \mathrm{H} 2 \mathrm{AX}$ foci as well as a higher level of the overall $\gamma \mathrm{H} 2 \mathrm{AX}$ prompted us to test the integrity of DNA in these cells. We quantified the number of apurinic/apyrimidinic (AP)-sites using ELISA. Single-stranded breaks (SSB) and DSB breaks were quantified using single-cell gel electrophoresis (comet assay) in alkaline conditions [32-34].

FSHD cells showed approximately 1.6 times more AP sites than normal myoblasts (Fig. 2E and Supplementary Fig. S1D), and the genomic DNA of normal cells contained significantly fewer breaks as compared to FSHD myoblasts, as shown by the analysis of the comet tail moment (TM) which reflects the degree of DNA damage (Fig. 3A, B and Supplementary Fig. S1 A, B, C). In addition, the analysis of the TM distribution was distinct between FSHD and normal myoblasts; the TM of the majority of FSHD cells ranged

Table 1

Top-10 protein-coding genes differentially expressed in FSHD myoblasts (MB) and myotubes (MT) from 6 FSHD patients, as compared to those from 5 normal individuals. Members of the same gene family were omitted; FC - Fold change FSHD vs. normal samples.

\section{MB upregulated}

\begin{tabular}{lll}
\hline FC & Gene name & Description: \\
\hline 7.1 & KCNA1 & $\begin{array}{l}\text { potassium channel, voltage gated shaker related } \\
\text { member 1 } \\
\text { calcitonin receptor }\end{array}$ \\
4.5 & CALCR & $\begin{array}{l}\text { zyg-11 family member A, cell cycle regulator } \\
\text { membrane protein, palmitoylated 4 (MAGUK p55 } \\
\text { m.4 }\end{array}$ ZYG11A \\
3.2 & MPP4 & $\begin{array}{l}\text { member 4) } \\
\text { collagen, type XIII, alpha 1 }\end{array}$ \\
2.8 & COL13A1 & protocadherin 9 \\
2.8 & PCDH9 & erythrocyte membrane protein band 4,1 like 4B \\
2.4 & EPB41L4B & zinc finger protein 367 \\
2.4 & ZNF367 & family with sequence similarity 111, member B \\
2.3 & FAM111B & transcription factor 19
\end{tabular}

303 more genes with $\mathrm{FC}>1.2$

MB downregulated

\section{MT upregulated}

\begin{tabular}{|c|c|c|}
\hline FC & Gene name & Description: \\
\hline 79.2 & RFPL2 & ret finger protein-like 2 \\
\hline 60.3 & TRIM43 & tripartite motif containing 43 \\
\hline 48.1 & PRAMEF1 & PRAME family member 1 \\
\hline 45.3 & TRIM64 & tripartite motif containing 64 \\
\hline 40.9 & LEUTX & leucine twenty homeobox \\
\hline 30.2 & SLC34A2 & $\begin{array}{l}\text { solute carrier family } 34 \text { (type II sodium/phosphate co- } \\
\text { transporter), member } 2\end{array}$ \\
\hline 28.9 & ZSCAN4 & zinc finger and SCAN domain containing 4 \\
\hline 25.7 & KHDC1 & $\mathrm{KH}$ homology domain containing 1 \\
\hline 22.8 & CCNA1 & cyclin A1 \\
\hline 17.8 & MBD3L3 & methyl-CpG binding domain protein 3-like 3 \\
\hline
\end{tabular}

61 more gene with $\mathrm{FC}>1.2$ MT downregulated

\begin{tabular}{|c|c|c|c|c|c|}
\hline FC & Gene name & Description: & FC & Gene name & Description: \\
\hline-7.5 & XAGE2 & $\mathrm{X}$ antigen family, member 2 & -16.6 & PCDH10 & protocadherin 10 \\
\hline-6.9 & PCDH10 & protocadherin 10 & -7.3 & AMPD1 & adenosine monophosphate deaminase 1 \\
\hline-5.9 & SEMA3E & $\begin{array}{l}\text { sema domain, immunoglobulin domain (Ig), short basic domain, } \\
\text { secreted, (semaphorin) 3E }\end{array}$ & -4.6 & TP63 & tumor protein p63 \\
\hline-5.3 & CLSTN2 & calsyntenin 2 & -3.6 & TRPA1 & $\begin{array}{l}\text { transient receptor potential cation channel, subfamily A, } \\
\text { member } 1\end{array}$ \\
\hline-4.8 & DGKB & diacylglycerol kinase, beta $90 \mathrm{kDa}$ & -3.1 & PIEZO2 & piezo-type mechanosensitive ion channel component 2 \\
\hline-4.4 & PGM5 & phosphoglucomutase 5 & -3.0 & RAET1E & retinoic acid early transcript $1 \mathrm{E}$ \\
\hline-4.2 & GRIP2 & glutamate receptor interacting protein 2 & -2.7 & BCAS1 & breast carcinoma amplified sequence 1 \\
\hline-3.5 & APOE & apolipoprotein E & -2.2 & TXLNB & taxilin beta \\
\hline-3.2 & VNN1 & vanin 1 & -2.2 & LMOD3 & leiomodin 3 (fetal) \\
\hline-3.2 & PRKG1 & protein kinase. cGMP-dependent, type I & -2.0 & LSMEM2 & leucine-rich single-pass membrane protein 2 \\
\hline
\end{tabular}


Table 2

Functional classification of the 54 DNA damage-related genes differentially expressed in FSHD.

Gene name Cell_cycle DNA_Replication DNA_repair Chromatin_organization Chromosome_segregation Cytoskeleton Meiosis Cell_signaling FC Description

\begin{tabular}{|c|c|c|c|c|c|c|c|c|c|c|}
\hline BLM & $\mathrm{x}$ & $\mathrm{X}$ & $\mathrm{x}$ & $\mathrm{x}$ & & & & & 1.9 & Bloom syndrome, RecQ helicase-like \\
\hline BRCA1 & $\mathrm{x}$ & $\mathrm{X}$ & $\mathrm{x}$ & & $\mathrm{X}$ & $\mathrm{x}$ & & & 1.7 & breast cancer 1 , early onset \\
\hline BRCA2 & $\mathrm{x}$ & $\mathrm{X}$ & $\mathrm{x}$ & $\mathrm{X}$ & & $\mathrm{x}$ & $\mathrm{x}$ & & 1.9 & breast cancer 2 , early onset \\
\hline CDC25C & $\mathrm{x}$ & $\mathrm{X}$ & $\mathrm{x}$ & & & & & & 1.9 & cell division cycle $25 \mathrm{C}$ \\
\hline CDC6 & $\mathrm{x}$ & $\mathrm{X}$ & $\mathrm{x}$ & & & & & & 1.9 & cell division cycle 6 \\
\hline CDK2 & $\mathrm{x}$ & $\mathrm{X}$ & $\mathrm{x}$ & & & & & & 1.8 & cyclin-dependent kinase 2 \\
\hline CDT1 & $\mathrm{x}$ & $\mathrm{X}$ & $\mathrm{x}$ & & & & & & 2.1 & chromatin licensing and DNA replication factor 1 \\
\hline CENPF & $\mathrm{x}$ & $\mathrm{x}$ & $\mathrm{x}$ & $\mathrm{x}$ & $\mathrm{x}$ & & & & 1.9 & centromere protein $\mathrm{F}, 350 / 400 \mathrm{kDa}$ \\
\hline CHAF1A & $\mathrm{x}$ & $\mathrm{X}$ & $\mathrm{x}$ & $\mathrm{X}$ & & & & & 1.6 & chromatin assembly factor 1 , subunit A ( 150 ) \\
\hline CHAF1B & $\mathrm{x}$ & $\mathrm{X}$ & $\mathrm{x}$ & $\mathrm{x}$ & & & & & 2.2 & chromatin assembly factor 1 , subunit B ( $p 60)$ \\
\hline CLSPN & $\mathrm{x}$ & $\mathrm{x}$ & $\mathrm{x}$ & & & & & & 2.1 & claspin \\
\hline DBF4 & $\mathrm{x}$ & $\mathrm{X}$ & $\mathrm{x}$ & & & & & & 1.6 & DBF4 zinc finger \\
\hline DSCC1 & $\mathrm{x}$ & $\mathrm{X}$ & $\mathrm{x}$ & $\mathrm{X}$ & $\mathrm{x}$ & & & & 1.9 & defective in sister chromatid cohesion 1 homolog (S. cerevisiae) \\
\hline DTL & & $\mathrm{X}$ & $\mathrm{x}$ & & & & & & 2.1 & denticleless E3 ubiquitin protein ligase homolog (Drosophila) \\
\hline $\mathrm{ESCO} 2$ & $\mathrm{x}$ & & $\mathrm{x}$ & & & & & & 2.0 & establishment of sister chromatid cohesion $\mathrm{N}$-acetyltransferase 2 \\
\hline EXO1 & $\mathrm{x}$ & & $\mathrm{x}$ & & & & $\mathrm{x}$ & & 1.8 & exonuclease 1 \\
\hline FANCC & & & $\mathrm{x}$ & & & & & & 1.4 & Fanconi anemia, complementation group $\mathrm{C}$ \\
\hline FANCD2 & $\mathrm{x}$ & & $\mathrm{x}$ & $\mathrm{X}$ & & & $\mathrm{X}$ & & 2.0 & Fanconi anemia, complementation group D2 \\
\hline FANCI & $\mathrm{x}$ & & $\mathrm{x}$ & & & & & & 1.7 & Fanconi anemia, complementation group I \\
\hline FEN1 & & $\mathrm{X}$ & $\mathrm{x}$ & & & & & $\mathrm{X}$ & 1.6 & flap structure-specific endonuclease 1 \\
\hline $\mathrm{H} 2 \mathrm{AFX}$ & $\mathrm{x}$ & & $\mathrm{x}$ & $\mathrm{X}$ & & & $\mathrm{x}$ & & 1.6 & $\mathrm{H} 2 \mathrm{~A}$ histone family, member $\mathrm{X}$ \\
\hline HELLS & $\mathrm{x}$ & & $\mathrm{x}$ & $\mathrm{X}$ & & & & & 1.9 & helicase, lymphoid-specific \\
\hline HMGB1 & & $\mathrm{X}$ & $\mathrm{x}$ & $\mathrm{X}$ & & & & & 1.5 & high mobility group box 1 \\
\hline KIF22 & $\mathrm{x}$ & & $\mathrm{x}$ & & & $\mathrm{X}$ & & & 1.6 & kinesin family member 22 \\
\hline LIN9 & $\mathrm{x}$ & $\mathrm{X}$ & $\mathrm{x}$ & & & & & & 1.7 & lin-9 DREAM MuvB core complex component \\
\hline MCM10 & & $\mathrm{X}$ & $\mathrm{x}$ & & & & & & 2.1 & minichromosome maintenance complex component 10 \\
\hline MCM2 & $\mathrm{x}$ & $\mathrm{X}$ & $\mathrm{x}$ & $\mathrm{X}$ & & & & & 1.7 & minichromosome maintenance complex component 2 \\
\hline MCM3 & $\mathrm{x}$ & $\mathrm{X}$ & $\mathrm{x}$ & & & & & & 1.8 & minichromosome maintenance complex component 3 \\
\hline MCM5 & $\mathrm{x}$ & $\mathrm{X}$ & $\mathrm{x}$ & & & & & & 1.8 & minichromosome maintenance complex component 5 \\
\hline MND1 & $\mathrm{x}$ & & $\mathrm{x}$ & & & & $\mathrm{X}$ & & 1.9 & meiotic nuclear divisions 1 homolog (S. cerevisiae) \\
\hline MSH2 & $\mathrm{x}$ & & $\mathrm{x}$ & $\mathrm{X}$ & & & & & 1.6 & mutS homolog 2 \\
\hline NEIL3 & & & $\mathrm{x}$ & & & & & & 2.2 & nei endonuclease VIII-like 3 (E. coli) \\
\hline PCNA & & $\mathrm{x}$ & $\mathrm{x}$ & & & & & $\mathrm{X}$ & 1.6 & proliferating cell nuclear antigen \\
\hline POLD3 & & $\mathrm{X}$ & $\mathrm{x}$ & & & & & & 1.6 & polymerase (DNA-directed), delta 3 , accessory subunit \\
\hline POLE2 & & $\mathrm{X}$ & $\mathrm{x}$ & & & & & & 2.1 & polymerase (DNA directed), epsilon 2, accessory subunit \\
\hline POLQ & & $\mathrm{X}$ & $\mathrm{x}$ & & & & & & 2.2 & polymerase (DNA directed), theta \\
\hline PRIM1 & & $\mathrm{X}$ & $\mathrm{x}$ & & & & & & 2.2 & primase, DNA, polypeptide 1 (49 $\mathrm{kDa})$ \\
\hline PSIP1 & & & $\mathrm{x}$ & & & & & & 1.9 & PC4 and SFRS1 interacting protein 1 \\
\hline RAD51 & $\mathrm{x}$ & $\mathrm{x}$ & $\mathrm{x}$ & & & & $\mathrm{x}$ & & 1.8 & RAD51 recombinase \\
\hline RAD51AP1 & & & $\mathrm{x}$ & & & & & & 1.9 & RAD51 associated protein 1 \\
\hline RECQL4 & & & $\mathrm{x}$ & & & & & & 1.5 & RecQ protein-like 4 \\
\hline RFC2 & & $\mathrm{X}$ & $\mathrm{x}$ & & & & & & 1.7 & replication factor C (activator 1 ) 2, $40 \mathrm{kDa}$ \\
\hline RFC4 & & $\mathrm{X}$ & $\mathrm{x}$ & & & & & $\mathrm{X}$ & 1.7 & replication factor $\mathrm{C}$ (activator 1) 4, $37 \mathrm{kDa}$ \\
\hline RFC5 & & $\mathrm{X}$ & $\mathrm{x}$ & & & & & & 2.0 & replication factor C (activator 1 ) 5, $36.5 \mathrm{kDa}$ \\
\hline RNASEH2A & & $\mathrm{X}$ & $\mathrm{x}$ & & & & & & 1.7 & ribonuclease $\mathrm{H} 2$, subunit $\mathrm{A}$ \\
\hline RPA1 & $\mathrm{x}$ & $\mathrm{x}$ & $\mathrm{x}$ & $\mathrm{X}$ & & & $\mathrm{x}$ & & 1.4 & replication protein $\mathrm{A} 1,70 \mathrm{kDa}$ \\
\hline RRM1 & & $\mathrm{x}$ & $\mathrm{x}$ & & & & & & 1.5 & ribonucleotide reductase $\mathrm{M} 1$ \\
\hline RRM2 & & $\mathrm{X}$ & $\mathrm{x}$ & & & & & & 2.2 & ribonucleotide reductase $\mathrm{M} 2$ \\
\hline TIPIN & $\mathrm{x}$ & $\mathrm{x}$ & $\mathrm{x}$ & & & & & & 1.6 & TIMELESS interacting protein \\
\hline TK1 & & $\mathrm{X}$ & $\mathrm{x}$ & & & & & & 1.7 & thymidine kinase 1 , soluble \\
\hline TOP2A & & $\mathrm{X}$ & $\mathrm{x}$ & $\mathrm{X}$ & $\mathrm{x}$ & & & $\mathrm{X}$ & 1.8 & topoisomerase (DNA) II alpha $170 \mathrm{kDa}$ \\
\hline TYMS & & $\mathrm{X}$ & $\mathrm{x}$ & & & & & $\mathrm{X}$ & 1.9 & thymidylate synthetase \\
\hline USP1 & & & $\mathrm{x}$ & & & & & & 1.5 & ubiquitin specific peptidase 1 \\
\hline WRAP53 & & & $\mathrm{x}$ & $\mathrm{x}$ & & & & & 1.5 & WD repeat containing, antisense to TP53 \\
\hline
\end{tabular}

WRAP53

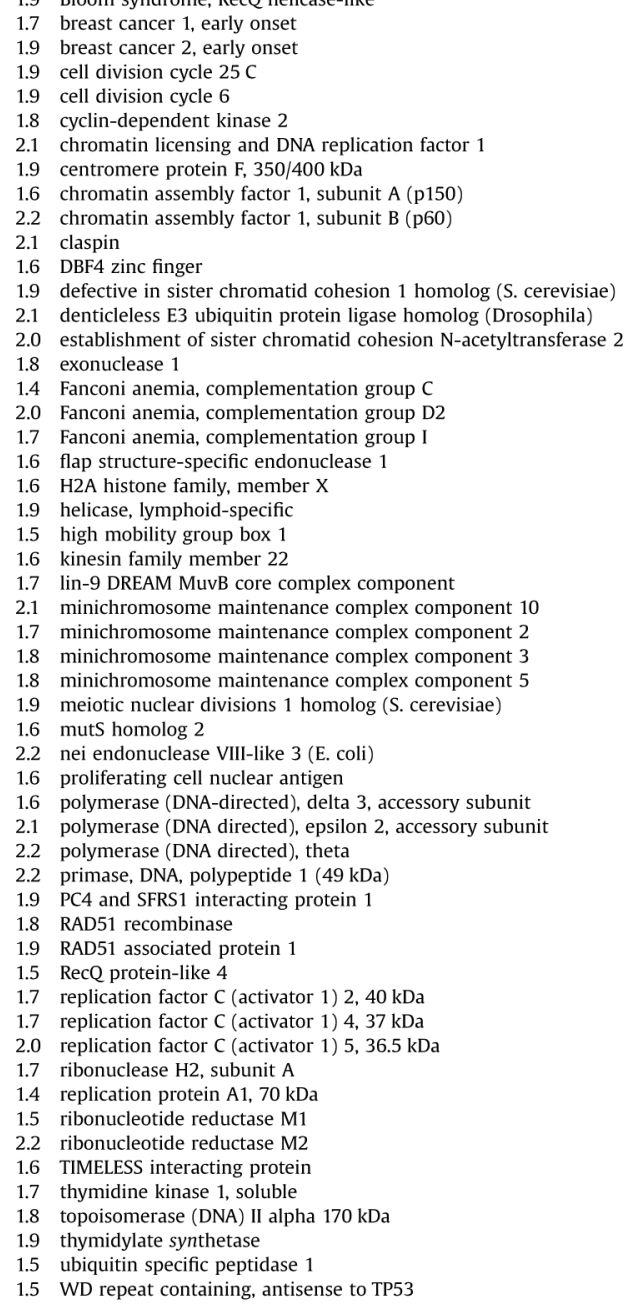


Functional classification of genes differentially expressed in FSHD. MB, Myoblasts, MT Myotubes, FDR False discovery rate. P-value and FDR of a supercluster (Supplementary Table S2) correspond to those of the most significant GO function within it.

\begin{tabular}{|c|c|c|c|}
\hline MB upregulated & No of genes & p-value & FDR \\
\hline Unique protein-coding genes $(\mathrm{FC}>1.2)$ & 313 & & \\
\hline Genes with a known function indexed in GO & 266 & & \\
\hline Best values for a random list & 266 & 1.60E-04 & 2.70E-01 \\
\hline \multicolumn{4}{|l|}{ Functional supercluster } \\
\hline Cell_cycle & 109 & $4.50 \mathrm{E}-72$ & $7.30 \mathrm{E}-69$ \\
\hline DNA_Replication_and_nucleotide_biosynthesis & 38 & $1.00 \mathrm{E}-29$ & $1.60 \mathrm{E}-26$ \\
\hline DNA_repair & 54 & $1.40 \mathrm{E}-28$ & $2.20 \mathrm{E}-25$ \\
\hline Chromosome_and_chromatin_organization & 68 & $1.60 \mathrm{E}-28$ & $2.50 \mathrm{E}-25$ \\
\hline Chromosome_segregation & 26 & $9.80 \mathrm{E}-26$ & $1.60 \mathrm{E}-22$ \\
\hline Microtubule_cytoskeleton_organization and localization & 34 & $8.20 \mathrm{E}-20$ & $1.30 \mathrm{E}-16$ \\
\hline Meiosis & 14 & $5.90 \mathrm{E}-09$ & $9.50 \mathrm{E}-06$ \\
\hline Cell_signaling & 18 & $1.70 \mathrm{E}-07$ & $2.70 \mathrm{E}-04$ \\
\hline Total unique genes & 170 & & \\
\hline MB downregulated & No of genes & p-value & FDR \\
\hline Unique protein-coding genes $(\mathrm{FC}<-1.2)$ & 88 & & \\
\hline Genes with a known function indexed in GO & 75 & & \\
\hline & 75 & 4.50E-03 & $6.60 E+00$ \\
\hline \multicolumn{4}{|l|}{$\begin{array}{l}\text { Significant functional category (DAVID) } \\
\text { none }\end{array}$} \\
\hline MT upregulated & No of genes & p-value & FDR \\
\hline Unique protein-coding genes $(\mathrm{FC}>1.2)$ & 71 & & \\
\hline Genes with a known function indexed in GO & 52 & & \\
\hline Best values for a random list & 52 & $9.80 \mathrm{E}-03$ & $1.40 \mathrm{E}+01$ \\
\hline \multicolumn{4}{|l|}{ Significant functional category (DAVID) } \\
\hline GO:0016477 cell migration & 4 & $9.70 \mathrm{E}-03$ & $9.9 \mathrm{E}-1$ \\
\hline MT downregulated & No of genes & p-value & FDR \\
\hline Unique protein-coding genes $(\mathrm{FC}<-1.2)$ & 38 & & \\
\hline Genes with a known function indexed in GO & 27 & & \\
\hline Best values for a random list & 27 & $6.70 \mathrm{E}-03$ & $8.90 \mathrm{E}+00$ \\
\hline $\begin{array}{l}\text { Significant functional category (DAVID) } \\
\text { none }\end{array}$ & & & \\
\hline
\end{tabular}

between 100 and 150 (a.u.), whereas the TM of the majority of normal cells varied between 40 and 100 (a.u.) (Fig. 3C and Supplementary Fig. S1).

Cellular responses to DNA damage may induce cell cycle arrest. We next followed the cell cycle progression of several cultures of primary FSHD and normal myoblasts using BrdU labeling. The analysis of FACS data did not reveal any statistically significant deviation of the cell cycle distribution between FSHD and normal cells (Supplementary Figure S2). This result was in agreement with previous reports [35-37] and our own observations that in vitro cultured FSHD cells proliferated similarly to normal controls.

Taken together, our data clearly demonstrate higher levels of DNA damage in the FSHD myoblasts, although the extent of this damage was insufficient for cell cycle arrest.

\subsection{DUX4 induces DNA damage in FSHD}

In vitro overexpression of human DUX4 gene in in vitro cultured mouse and human myogenic progenitor cells has been shown to interfere with their myogenic differentiation and to increase sensitivity to oxidative stress [27] thus reproducing some features of cultured FSHD myoblasts. In addition, overexpression of the human DUX4 gene caused atrophy [38] and apoptosis [39] in human cells cultured in vitro and was deleterious for mouse and zebrafish muscles in vivo $[40,41]$. Together with the observation that RNAimediated DUX4 inhibition was sufficient to reverse morphological abnormalities found in cultured FSHD myotubes [38], these findings suggest that DUX4 overexpression may be one of the causes of FSHD.

To address the possibility that DUX4 might be also responsible for higher levels of DNA damage observed in FSHD cells, we overexpressed DUX4 in human immortalized myoblasts and found that the level of DNA damage measured by the comet assay was 1.5 times higher in DUX4-overexpressing cells (Fig. 4A, B, C and Supplementary Figure S3). Similarly, the number of AP sites was two times higher in DUX4-overexpressing myoblasts as compared to the control cells (Fig. 4D). Furthermore, the analysis of $\gamma \mathrm{H} 2 \mathrm{AX}$ and DUX4 co-localization by immunofluorescence revealed that these two proteins were co-localized in $75 \%$ of DUX4-transfected cells versus 35\% of GFP-transfected cells (Fig. 4E), and the overall level of $\gamma \mathrm{H} 2 \mathrm{AX}$ phosphorylation was higher in DUX4-overexpressing cells as compared to the control cells (Fig. $4 \mathbf{F}$ and $\mathbf{G}$ ).

We then transfected primary myoblasts isolated from FSHD patients with siRNA against DUX4 and found that the DUX4 knockdown diminished the level of DNA damage in FSHD myoblasts (Fig. 5). Taken together, our results demonstrate that the induction of DNA damage might be a novel FSHD-related function of DUX4.

FSHD cells are highly sensitive to oxidative stress [19,20,27]. However, a direct role of DUX4 in the induction of oxidative stress has never been demonstrated. In order to determine the role of DUX4 in ROS generation, we have overexpressed DUX4 in human immortalized myoblasts and measured the level of ROS using the dihydroethidium (DHE), a ROS fluorescent sensor probe that, once oxidized in the presence of cellular oxidants, exhibits a red fluorescence. We observed that the level of ROS was increased in DUX4overexpressing myoblasts as compared to the controls (Fig. 6A, C and Supplementary Figure S4A). Furthermore, we confirmed this result by a complementary sensitive approach that uses Amplex Red probe (10-acetyl-3,7-dihydroxyphenoxazine) to detect $\mathrm{H}_{2} \mathrm{O}_{2}$ 

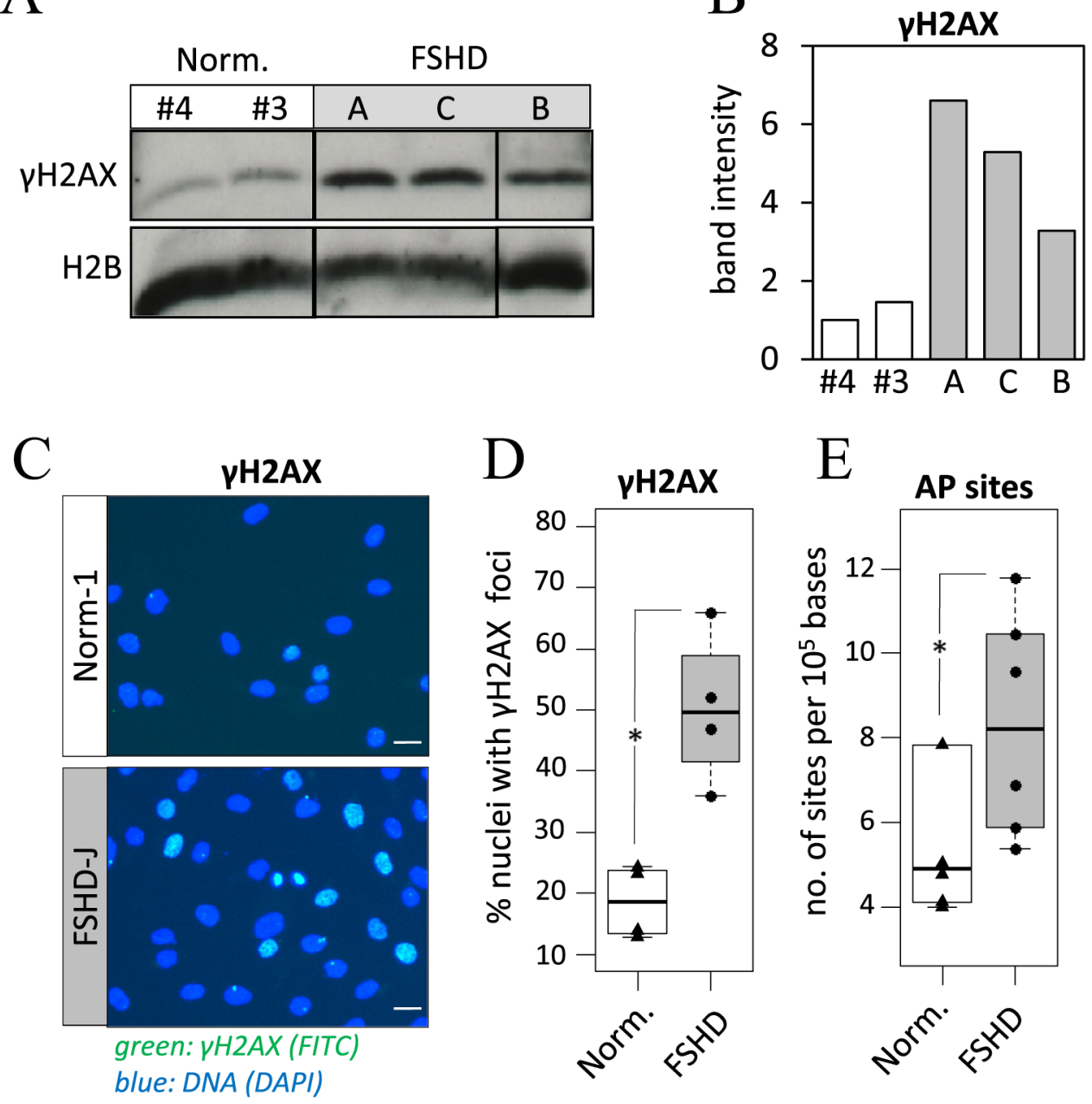

Fig. 2. DNA damage markers in FSHD myoblasts. A. Western blot analysis of $\gamma H 2 A X$ protein levels in FSHD primary myoblasts from FSHD patients (FSHD-A,B,C) and healthy controls (Norm-3,4). B. Densitometry quantification of the western blot images shown in panel A, $\gamma \mathrm{H} 2 \mathrm{AX}$ was normalized to H2B protein levels. C. Immunofluorescent imaging of $\gamma \mathrm{H} 2 \mathrm{AX}$ foci labeled with Alexa 488 in primary myoblasts from the FSHD patient FSHD-J and a healthy subject Norm-1; representative images are shown; 20X magnification, bar $=10 \mu \mathrm{m}$. D. Quantification of nuclei of primary myoblasts from four healthy subjects Norm-1,3,6,5 (triangles) and four FSHD patients FSHD-E,G,H,J (dots) containing $\gamma \mathrm{H} 2 \mathrm{AX}$ foci. Each dot/triangle in the boxplot represents the percentage of $\gamma \mathrm{H} 2 \mathrm{AX}$ foci in one cell culture, calculated from at least $100 \mathrm{nuclei}$. $\left({ }^{*}\right)$ - $t$-test $\mathrm{p}$-value $<0.05$. For given sample size and type I error rate alpha $=5 \%$, power $=0.95$. E. Average number of apurinic/apyrimidinic (AP) sites in primary myoblasts from six FSHD patients (FSHD-A,B,C,D,E,F) and five healthy controls (Norm-2,3,4,5,6); $\left.{ }^{*}\right) t$-test p-value $<0.05$.

released to the extracellular space (Supplementary Figure S5) [42].

We hypothesized that the increased production of ROS in DUX4-overexpressing cells was a direct cause of DNA damage; therefore we treated DUX4-transfected cells with tempol, a potent antioxidant, and found that in the presence of tempol, the level of ROS significantly decreased (Fig. 6 A, B, C and Supplementary Figure S4B, C) and the amount of DNA lesions was similar in DUX4transfected cells as in mock-transfected and GFP-transfected cells (Fig. 4A, B, C and Supplementary Figure S3). This result indicates that the mechanism of DNA damage induced by DUX4, involves increased production of ROS in the cell.

\subsection{DNA damage in FSHD myoblasts is provoked by ROS}

Despite a number of studies, the oxidative stress has never been directly demonstrated in in vitro cultured FSHD cells. By measuring DHE fluorescence, we found that the level of ROS was considerably higher in in vitro cultured FSHD myoblasts as compared to normal controls (Fig. 6D, E, F and Supplementary Figure S6).

We then asked whether the DNA damage observed in in vitro cultured primary myoblasts from FSHD patients could be linked to oxidative stress. Thus we treated the FSHD myoblasts with tempol and quantified the level of DNA damage using comet assay. Our data clearly indicate that antioxidant-treated FSHD cells have a level of DNA damage indistinguishable from normal cells (Fig. 7). We concluded that the high level of DNA damage observed in FSHD myoblasts is provoked by higher levels of ROS.

\subsection{DNA damage and ROS affect myogenic differentiation of FSHD myoblasts}

In vitro cultured FSHD myoblasts give rise to abnormal myotubes upon myogenic differentiation induced by serum starvation [19]. These defects in differentiation could be due, at least partly, to overexpression of DUX4 [38]. DNA damage and ROS can interfere with signal transduction pathways as they can act as second messengers for various physiological stimuli [43] and can thereby affect myotube formation and have pathological implications.

We have selected a primary FSHD culture, FSHD-F, known to differentiate into atrophic myotubes $[18,19]$. We treated proliferating myoblasts with $100 \mu \mathrm{M}$ antioxidant tempol and $48 \mathrm{~h}$ post-treatment induced myogenic differentiation by serum starvation in the presence of tempol. Six days post-differentiation, 

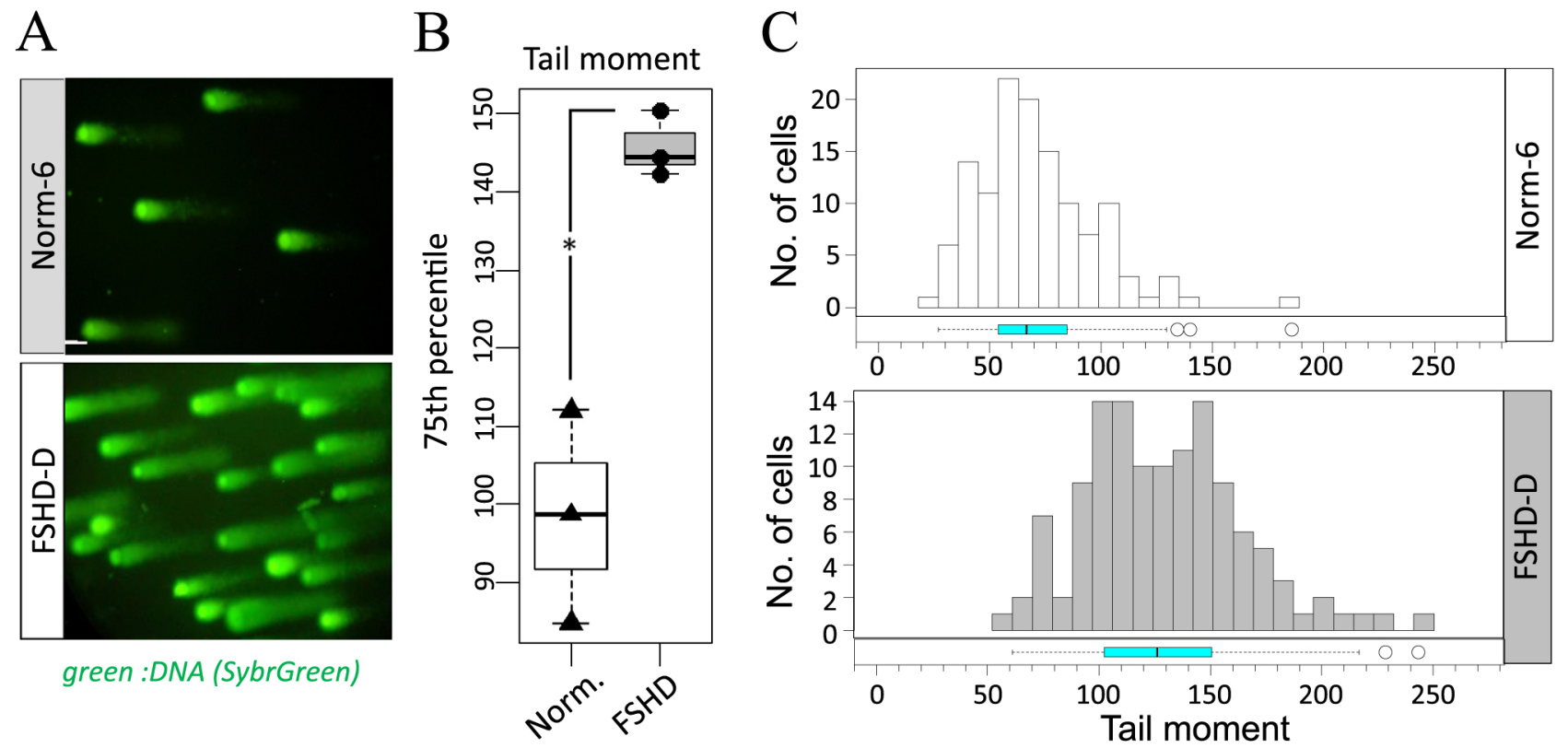

Fig. 3. DNA damage in FSHD myoblasts. A. Fluorescent imaging of primary myoblasts isolated from the FSHD patient FSHD-D and a healthy subject Norm- 6 subjected to a single-cell electrophoresis (comet assay) and stained with SybrGreen; representative images are shown, 20X magnification, bar $=10 \mu \mathrm{m}$; B. 75 th percentiles of comet tail moment distributions measured in primary myoblasts from three FSHD patients (FSHD-D,E,F) and three healthy controls (Norm-4,5,6), for each primary myoblast culture, at least 100 cells were analyzed; $\left(^{*}\right) t$-test p-value $<0.05$. For given sample size and type I error rate alpha $=5 \%$, power $=0.989$. C. Histogram and horizontally oriented boxplot showing the distribution of comet tail moments measured in primary myoblasts from patient FSHD-D (124 cells analyzed) and a healthy subject Norm-6 (125 cells analyzed); Distributions for other lines analyzed are shown in Supplementary Fig. S1.

non-treated FSHD-F myotubes were thin and atrophic, with a mean diameter of $11.7 \mu \mathrm{m}$. In the presence of tempol, the number of myotubes with larger diameter significantly increased and diameter reached a mean value of $15.1 \mu \mathrm{m}$ (Fig. 8). We then tested another powerful antioxidant, N-Acetyl-L-cysteine (NAC), on FSHD-F myoblasts. NAC is a derivative of L-cysteine; its antioxidant activity is due to its ability to interact with the electrophilic groups of free radicals due to the presence of free thiol groups [44]. NAC was highly efficient and the diameter of NAC-treated FSHD-F myotubes (mean value of $21.3 \mu \mathrm{m}$ ) was closer to that of normal Norm-7 myotubes (mean value of $26.2 \mu \mathrm{m}$ ). These results suggest that oxidative stress affects myogenic differentiation process of FSHD myoblasts; it specifically contributes to establishment of phenotypically aberrant myotubes. The antioxidant treatment significantly improved the phenotype of FSHD myotubes.

\section{Discussion}

Here we performed a transcriptome profiling of CD56 ${ }^{+}$FSHD myoblasts cultured in vitro by including a step of specific enrichment for myogenic cells and, thus avoided working on complex cell mixtures containing inflammatory-, connective tissue-, adipose tissue- and other cells; this excluded possible artifacts potentially introduced by the external factors such as inflammatory cells infiltrating FSHD muscles [45]. Previously, transcriptome and proteome profiling of FSHD biopsies and myoblasts demonstrated an abnormal expression of myogenesis-related mRNA and miRNAs $[4-7,12,17]$; cytoskeleton proteins [15]; genes related to oxidative stress $[8,11,12,20]$; vascular smooth muscle and endothelium cellspecific genes [9]; germline-related genes [13,14], genes specific to immune system [10] and others. Furthermore, abnormal expression of cell cycle-related genes has been documented using in vitro cultured FSHD myoblasts [11] and FSHD tissue samples [46]. In agreement with previous reports, we have found genes related to cytoskeleton (i.e. DIAPH3, PSRC1, TACC3) and oxidative stress (i.e. APOE, TRPA1, VNN1). Our transcriptome analysis also revealed an upregulation of many genes related to DNA damage repair in FSHD myoblasts. The probability of finding this group of genes linked by the common function by chance was very low (pvalue $=1.4 \times 10^{28}$ ) and suggested the presence of a higher level of DNA damage in FSHD cells which was not previously observed. Here, by means of several techniques, we have demonstrated constitutive DNA damage in FSHD myoblasts.

Major DNA lesions include single-stranded DNA breaks (SSBs), double-stranded DNA breaks (DSBs) and abasic sites (AP-sites); they may be caused by external factors such as ionizing radiation, xenobiotic chemicals, UV, etc $[47,48]$ and endogenous sources such as cellular metabolism [49], replicative stress and replicative fork collapse [50].

Since in vitro cell culture conditions excluded that the increased DNA damage in FSHD cells was due to external genotoxic factors, we focused on internal sources of DNA damage. At first, we ruled out the possibility that the DNA damage observed in FSHD cells was due to the replicative stress since in our experimental conditions, FSHD myoblasts were cycling normally and no difference in cell cycle progression was observed.

Another major internal cause of genomic DNA damage is cellular metabolism (for review see [28]) that routinely produces free radicals (ROS) reacting with the purine and pyrimidine bases and phosphate backbone of DNA.

As mentioned above, in vitro cultured myoblasts isolated from FSHD patients are sensitive to oxidative stress inducers Paraquat and $\mathrm{H}_{2} \mathrm{O}_{2}[19,20]$. Coupled with the observation that the expression and biological activity of enzymes controlling the redox balance is altered in FSHD patients [22] these reports suggested that FSHD myoblasts might suffer from the endogenous oxidative stress, however, this has never been directly demonstrated before. Here, using fluorescent reactive oxygen species (ROS) sensor DHE, we could demonstrate that FSHD myoblasts contain higher level of ROS as compared to normal cells thus confirming the presence of oxidative stress in FSHD myoblasts in vitro. The DHE results were confirmed by Amplex Red data.

We then focused on the possibility that ROS was the major 


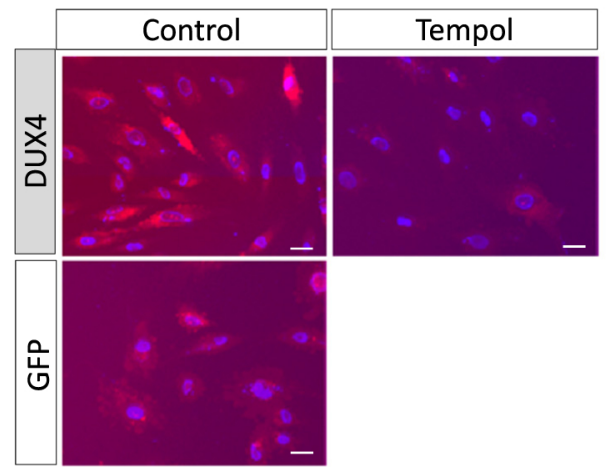

blue: DNA (DAPI), red: ROS (DHE)

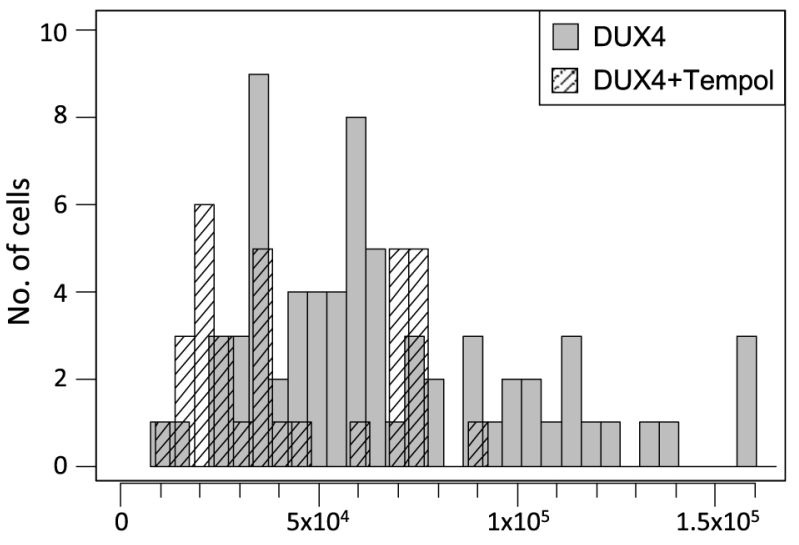

Fuorescence, a.u.

E

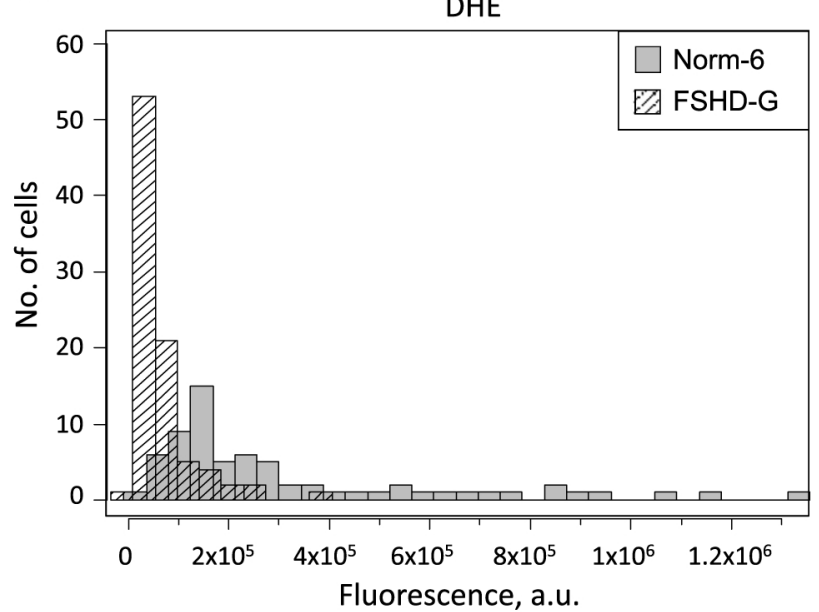

C

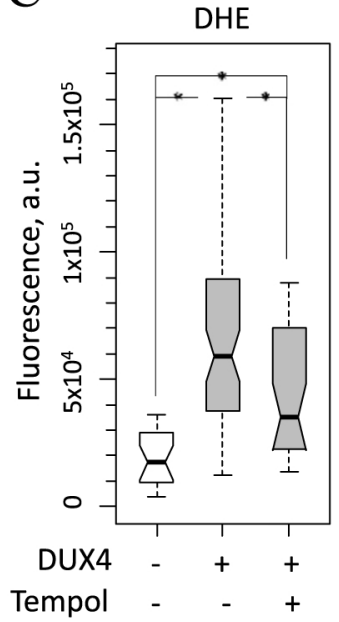

$\mathrm{F}$

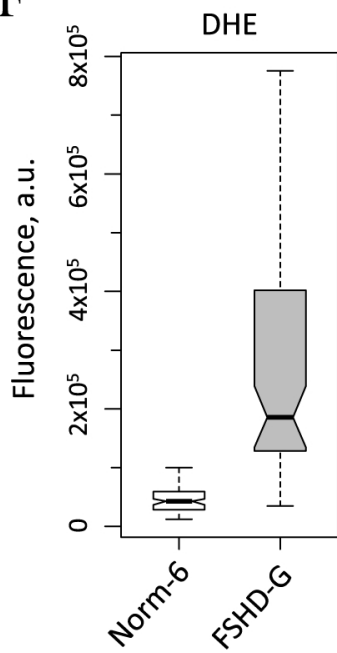

Fig. 6. Oxidative stress in FSHD primary myoblasts and in DUX4-transfected human myoblasts. A. Immunofluorescent imaging of human immortalized myoblasts transfected with pCI-Neo-DUX4 or control plasmid (phrGFP-N1), treated or not with tempol and stained with a fluorescent ROS sensor probe dihydroethidium (DHE); representative images are shown, 20X magnification, bar $=10 \mu \mathrm{m}$. B. Effect of tempol on the distribution of DHE fluorescence intensity in human immortalized myoblasts transfected with DUX4, 33 cells analyzed for "+ tempol" condition and 69 cells - for "-tempol" condition. C. Statistical analysis of DHE fluorescence intensity distribution of samples shown on A. $\left(^{*}\right) t$-test p-value $<0.05$. Notches indicate a confidence interval. D. Reactive oxygen species (ROS) visualization via DHE fluorescence analysis in primary myoblasts from the FSHD patient FSHD-G and a healthy subject Norm-6; representative images are shown, $20 \mathrm{X}$ magnification, bar $=10 \mu \mathrm{m}$. E. Distribution of DHE intensity in myoblasts from the FSHD patient FSHD-G (68 cells analyzed) and a healthy subject Norm-6 (89 cells analyzed) and its statistical analysis $(\mathbf{F})\left({ }^{*}\right) t$-test p-value $<0.05$.

and preserved in liquid nitrogen for future use. After unfreezing, the myoblasts were cultured for one more passage in high-glucose DMEM (here and below Sigma \#D6546) supplemented with 10\% FBS (Millerium \#BWSTS1810/500), 1\% Ultroser G (Biosepra \#15950-017), 4 mM L-glutamine (Sigma \#68540-25G), $50 \mu \mathrm{g} / \mathrm{mL}$ gentamicin (Sigma \#G1397) and $1 \mu \mathrm{g} / \mathrm{mL}$ Amphotericin B (Fungizone, Gibco \#15290-018) and then switched to the proliferation medium (DMEM, 20\% FBS, $4 \mathrm{mM}$ L-glutamine, $50 \mu \mathrm{g} / \mathrm{mL}$ gentamicin $1 \mu \mathrm{g} / \mathrm{mL}$ Amphotericin), passaged at a cell confluency not exceeding $30 \%$ and used for transfection and tests up to passage 10 to avoid cellular senescence and spontaneous differentiation. To induce the myogenic differentiation, the myoblasts were grown to confluency in proliferating medium, switched to differentiation medium (DMEM, 2\% FBS, $4 \mathrm{mM}$ L-glutamine, $50 \mu \mathrm{g} / \mathrm{mL}$ gentamicin $1 \mu \mathrm{g} / \mathrm{mL}$ Amphotericin) and cultured for 6 days without medium change. pMyo were cultured in cell culture dishes coated with collagen using sterile a $0.1 \%$ solution of collagen powder (Sigma \#C7661) in 0.2\% acetic acid.

Human immortalized myoblasts LHCN-M2 derived from a healthy subject ("iMyo") (a kind gift from Dr. V. Mouly, Institute of Myology, Paris) were cultured in the media composed of 4 parts of high-glucose DMEM, 1 part of Medium 199 (Sigma \#M4530) and supplemented with $20 \% \mathrm{FBS}, 1 \mathrm{X}$ penicillin/streptomycin (Gibco \#15140-122) and $2.5 \mu \mathrm{g} / \mathrm{mL}$ plasmocin (Invivogen \#MPP-35-02).

The rhabdomyosarcoma cell line TE-671 (a kind gift from Dr. S. Leibowitz, Institut Gustave Roussy, France) was cultured in DMEM supplemented with $10 \%$ FBS, $2 \mathrm{mM}$ L-glutamine, 100 units/mL Penicillin G, $100 \mu \mathrm{g} / \mathrm{mL}$ Streptomycin sulfate (Gibco \#15070-063) and $1 \mu \mathrm{g} / \mathrm{mL}$ Amphotericin B.

pMyo were transfected using $4 \mu \mathrm{L}$ of siPORTNeoFX and $10 \mathrm{nM}$ DUX4 siRNA mix or control siRNA using a "reverse" transfection schema as previously described [38]. iMyo transfection was carried out in 6-well plates. 200,000 cells in $1 \mathrm{~mL}$ of culturing medium were mixed with $200 \mu \mathrm{L}$ of OptiMEM (Gibco \#31985062) containing $600 \mathrm{ng}$ of plasmid DNA and $0.6 \mu \mathrm{L}$ Lipofectamine 2000 (Invitrogen \#11668-019) per well using a "reverse" transfection schema.

$24 \mathrm{~h}$ prior to transfection, TE-671 cells were plated in a 6 well plate at the density $2.5 \times 10^{5}$ cells/well and then transfected using $3 \mu \mathrm{g}$ of plasmid DNA and $6 \mu \mathrm{L}$ JetPEI (Polyplus \#101-10) in $300 \mu \mathrm{L}$ of $150 \mathrm{mM} \mathrm{NaCl}$ per well.

To overexpress DUX4, the plasmid pCI-NeoDUX4 containing the ORF of human DUX4 gene under control of the CMV promoter 

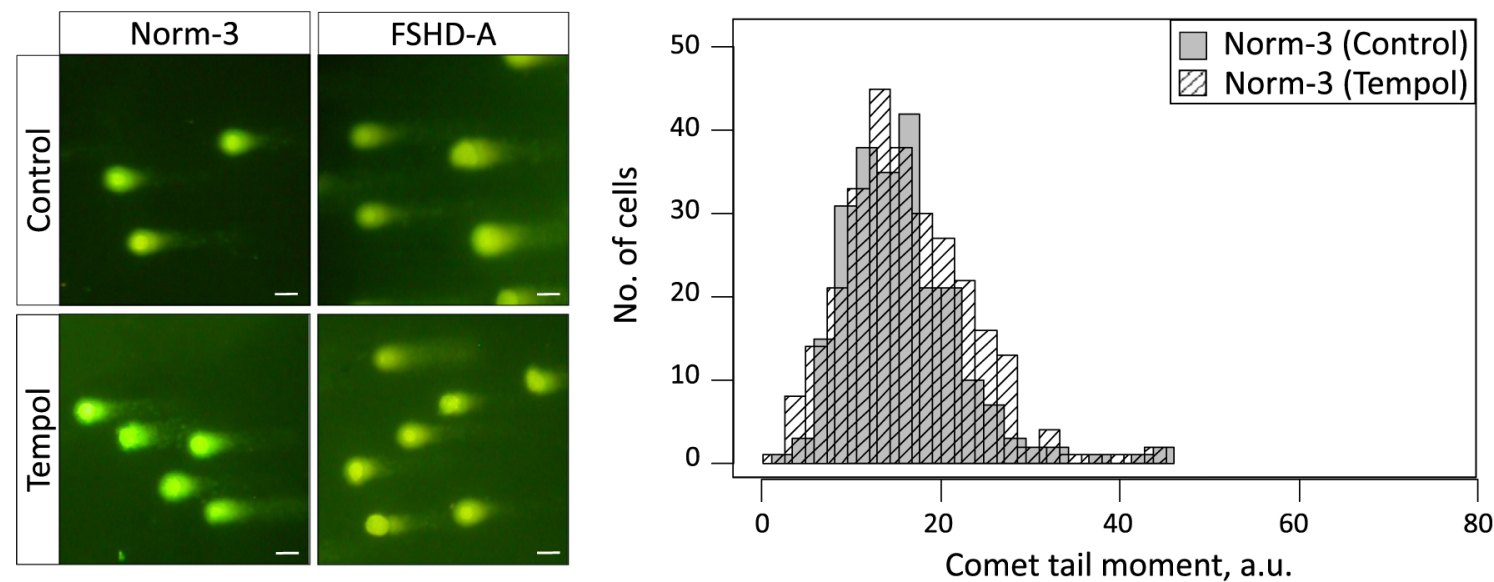

$\mathrm{D}$
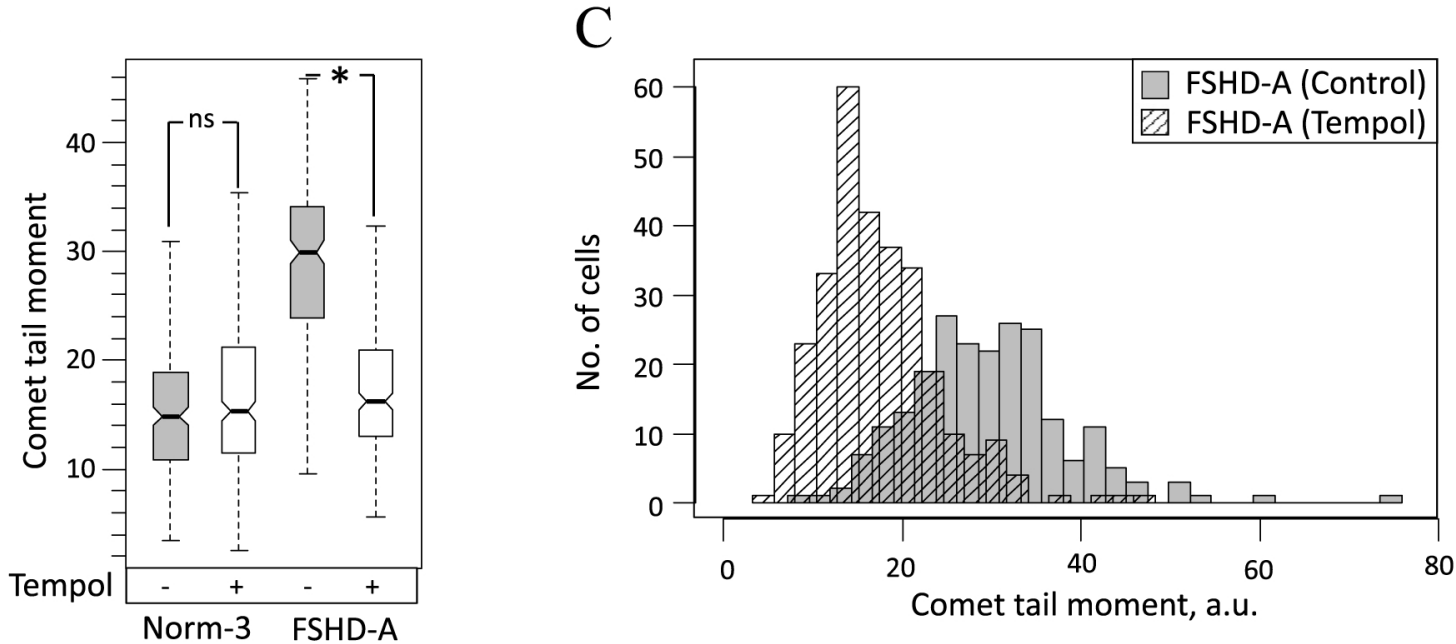

Fig. 7. Effect of the antioxidant addition to the culture medium on the constitutive DNA damage in FSHD myoblasts. A. DNA integrity of primary myoblasts from the FSHD patient FSHD-A and a normal subject Norm-3 cultured in the medium supplemented or not with $100 \mu \mathrm{M}$ of tempol was analyzed using comet assay in alkaline conditions, representative images with $20 \mathrm{X}$ magnification are shown. B,C. Effect of the culture medium supplementation with $100 \mu \mathrm{M}$ tempol on the distribution of comet tail moments in normal myoblasts (Norm-3, 207 untreated and 284 tempol-treated cells analyzed) (B) and FSHD myoblasts (FSHD-A, 224 untreated and 293 tempol-treated cells analyzed) (C). D. Statistical analysis of distributions shown in panels B and C; $\left(^{*}\right) t$-test p-value $<0.05$.; ns - non-significant.

(a kind gift from Alexandra Belayew and Frederique Coppée, University of Mons, Belgium) was used; as a control pCl-Neo (Promega) and phrGFP-N1 (Stratagen) plasmids were used.

To test the effect of tempol on the level of DNA damage in pMyo, the culture medium was supplemented with $100 \mu \mathrm{M}$ tempol (Enzo Life Sciences \#ALX-430-081) or DMSO as a control (in water) 2 days before the DNA damage analysis; the medium was replaced every $24 \mathrm{~h}$. To test the effect of tempol on the level of DNA damage in iMyo, the culture medium was supplemented with $100 \mu \mathrm{M}$ tempol $3 \mathrm{~h}$ before the transfection; the tempol treatment was renewed $24 \mathrm{~h}$ after the transfection, and the DNA damage analysis was carried out $48 \mathrm{~h}$ post-transfection.

\subsection{Immunofluorescence staining and quantification}

Proliferating pMyo were, fixed with 2\% PFA (Euromedex) for 5 min, permeabilized with $0.25 \%$ Triton X-100 (Sigma-Aldrich) for 5 min, blocked with $0.5 \%$ BSA (Euromedex), incubated with mouse monoclonal antibodies against $\gamma \mathrm{H} 2 \mathrm{AX}$ (phospho Ser139 H2AX Active Motif \#39117, 1:500) or mouse monoclonal anti-Troponin T (Sigma \# T6277, 1:50) for $1 \mathrm{~h}$, stained with Alexa Fluor 488 antimouse IgG (Life Technologies \#A-21200, 1:100) for $1 \mathrm{~h}$, mounted with a mounting medium containing DAPI (Vector laboratories) and observed under a fluorescent microscope (Microvision instruments, excitation/emission: 488/519 nm, green fluorescence). To create a full image of the specimen, images of adjacent fields were stitched together using Cartograph software (Microvision). For $\gamma \mathrm{H} 2 \mathrm{AX}$ and DUX4 co-staining, proliferating iMyo transfected with pCI-NeoDUX4 or phrGFP-N1 were incubated simultaneously with a mouse monoclonal antibody against DUX4 (9A12 kindly donated by Alexandra Belayew, University of Mons, Belgium) and rabbit polyclonal antibodies against $\gamma \mathrm{H} 2 \mathrm{AX}$ (phospho Ser139 H2AX Active Motif \#39117, 1:500), stained with Alexa Fluor 488-conjugated anti-mouse IgG (Life Technologies\#A-21200, 1:100, excitation/emission: $488 / 519 \mathrm{~nm}$, green fluorescence) and Alexa Fluor 514-conjugated anti-rabbit IgG (Life Technologies \#A$31558,1: 100$, excitation/emission: 518/540 nm, red fluorescence).

\subsection{ROS staining in living cells}

$48 \mathrm{~h}$ after the transfection, iMyo were incubated in a $5 \mathrm{mM}$ DHE-containing ROS staining solution diluted 1:8000 in the $1 \mathrm{X}$ proprietary assay buffer (Muse oxidative stress kit, Millipore) for $15 \mathrm{~min}$ in the dark at room temperature with shaking, washed three times with PBS, mounted using a DAPI mounting medium (Vector laboratories), observed under a fluorescent microscope (excitation/emission: 520/610 nm, red fluorescence). Images from adjacent fields of view were stitched together by using the 

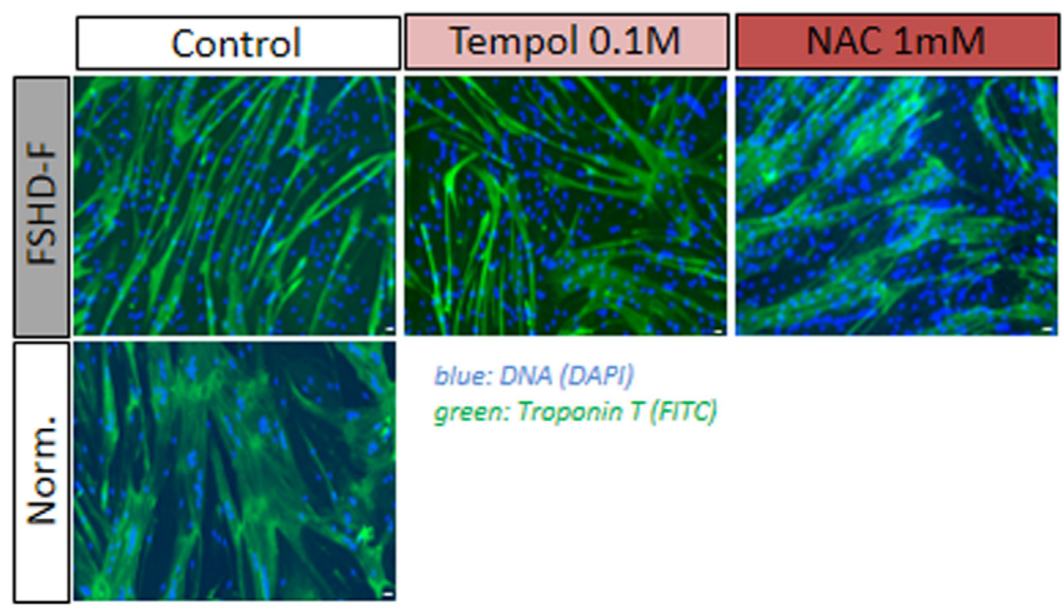

blue: DNA (DAPI)

green: Troponin T (FITC)
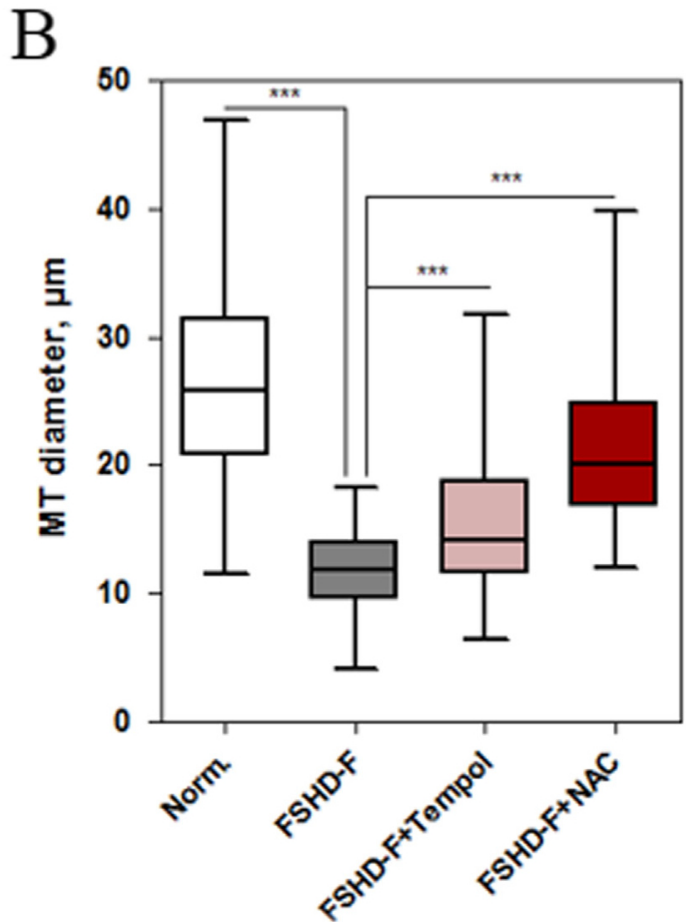

Fig. 8. Effect of the antioxidants on the morphology of FSHD myotubes. A. Immunofluorescent imaging of myotubes (MT) derived from atrophic (FSHD-F) primary myoblasts isolated from an FSHD patient or a healthy control (Norm-7); green: Troponin T, blue: DAPI. 10X magnification, bar $=10 \mu \mathrm{m}$. Full-size images are shown on Supplementary Fig. S8. B. Statistical analysis of diameter measurements of normal and FSHD-F myotubes before and after antioxidant treatment; $(* * *) t$-test p-value $<0.001$.

Cartograph software (Microvision) to create one large image of the specimen. The fluorescence of at least 100 cells per sample was quantified with Image $(\mathrm{NIH})$ using the formula: CTCF (corrected total cell fluorescence $)=$ Integrated_Density - (Area_of_selected _cell X Mean_fluorescence_of_background_readings).

\subsection{Measurement of $\mathrm{H}_{2} \mathrm{O}_{2}$ generation}

$\mathrm{H}_{2} \mathrm{O}_{2}$ generation was quantified by the Amplex red/horseradish peroxidase assay (Sigma Aldrich), which detects the accumulation of a fluorescent oxidized product, according to a previously published protocol [42]. Cells (5.10 ${ }^{4}$ ) in Dulbecco's phosphate-buffered saline (D-PBS) with $\mathrm{CaCl} 2$ and $\mathrm{MgCl} 2$ were incubated with D-glucose $(1 \mathrm{mg} / \mathrm{mL})$, horseradish peroxidase $(0.5 \mathrm{U} / \mathrm{mL}$; Roche), and Amplex red ( $50 \mu \mathrm{M}$; Sigma Aldrich), and immediately the fluorescence was measured in a microplate reader (Victor3; PerkinElmer) at $37^{\circ} \mathrm{C}$ for $1 \mathrm{~h}$ using excitation at $530 \mathrm{~nm}$ and emission at $595 \mathrm{~nm} \cdot \mathrm{H}_{2} \mathrm{O}_{2}$ release was quantified (nanomoles $\mathrm{H}_{2} \mathrm{O}_{2}$ per hour per $10^{5}$ cells) using standard calibration curves.

\subsection{Western blot}

Whole cell protein extracts were prepared from frozen myoblast cell pellets using TENT buffer ( $150 \mathrm{mM} \mathrm{NaCl}, 1 \mathrm{mM}$ EDTA, 50 mM Tris- $\mathrm{HCl}$ pH7.5, 0.5\% NP-40) [58] supplemented with antiprotease and anti-phosphatase inhibitor cocktails (Roche \#04693159001, \#04906845001), separated on 15\% (for $\gamma \mathrm{H} 2 \mathrm{AX}$ and H2B staining) or $8 \%$ polyacrylamide gel depending on the protein molecular weight, transferred to a nitrocellulose membrane, blocked with 5\% BSA/PyTBST (for staining of phosphorylated proteins) or $5 \%$ milk/PyTBST, hybridized with primary antibodies against $\gamma \mathrm{H} 2 \mathrm{AX}$ (phospho Ser139 H2AX \#ab11174, Abcam), H2B (SantaCruz \#sc8650), Actin (Millipore \#mab1501), washed with 1X PyTBST (10 mM Tris- $\mathrm{HCl}$ pH7.4, 75 mM NaCl, 1 mM EDTA, 0.1\% Tween 20) [59] to reduce background, hybridized with secondary antibodies conjugated to HRP (SantaCruz \#sc2030, \#sc2768, \#sc2005), revealed with $E C L+($ GE Healthcare), exposed to X-ray film (Amersham) and developed in the chemical film processor (FujiFilm). Quantification of scanned X-ray images was performed using ImageJ.

\subsection{FACS analysis}

Proliferating pMyo were cultured for $5 \mathrm{~h}$, as described above in the presence of $10 \mu \mathrm{M}$ BrdU (Sigma \#B5002-100G) freshly dissolved in PBS, trypsinized, centrifuged, resuspended in PBS and fixed at $4{ }^{\circ} \mathrm{C}$ overnight in $60 \%$ Ethanol at a final concentration of $1 \times 10^{6}$ cells $/ \mathrm{mL}$, the DNA was then denatured in $2 \mathrm{~N} \mathrm{HCl}$ for $20 \mathrm{~min}$ at $37^{\circ} \mathrm{C}$, neutralized with $500 \mathrm{mM}$ of sodium borate, washed with PBTB (PBS supplemented with $0.5 \%$ Tween 20 and $0.5 \%$ BSA), incubated with anti-BrdU antibodies (Sigma \#B8434, $2 \mu \mathrm{g}$ / $\mu \mathrm{L}, 1: 100)$ in $100 \mu \mathrm{L}$ of PBTB for $1 \mathrm{~h}$ at room temperature in the dark, diluted 10-fold with $\mathrm{PBTB}$, centrifuged, incubated for $1 \mathrm{~h}$ at room temperature in the dark with anti-mouse antibody conjugated to Alexa Fluor 488 (Invitrogen \#A11059, $2 \mathrm{mg} / \mathrm{mL}, 1: 200$ ) diluted 10-fold with PBTB, centrifuged, resuspended in $500 \mu \mathrm{L}$ of PBTB, stained with $10 \mu \mathrm{g} / \mathrm{mL}$ of PI for $15 \mathrm{~min}$ at room temperature in the dark and treated with $20 \mu \mathrm{g} / \mathrm{mL}$ of RNAse I for $30 \mathrm{~min}$. Cell cycle distribution data were obtained using FACS Calibur (BD Bioscience) and analyzed using FCS Express v3.

\subsection{Apurinic/apyrimidinic site quantification}

Genomic DNA was isolated using Nucleospin Tissue kit (Macherey Nagel). AP sites were quantified using DNA damage colorimetric assay kit (Abcam \#ab65353) as instructed by the producer. Briefly, 500 ng of genomic DNA were labeled with aldehydereactive probe (ARP) containing a biotin moiety, immobilized in microwells, incubated with streptavidin-conjugated HRP; following an HRP substrate addition, the absorbance $(650 \mathrm{~nm})$ was 
measured using a microplate absorbance reader. To translate the absorbance units into the number of AP sites, a standard curve was obtained using control DNA containing 40 AP sites per $10^{5} \mathrm{bp}$.

\subsection{Alkaline Comet assay and scoring for DNA damage}

The alkaline comet assay was performed using the Trevigen CometAssay kit (Trevigen \# 4,250,050-k) and 20-well CometSlide $^{\mathrm{TM}}$ (Trevigen \# 4252-500-01). Briefly, the cells were combined at $1 \times 10^{5} / \mathrm{mL}$ with a molten low melting point agarose (LMAgarose) at $37^{\circ} \mathrm{C}$ at the ratio of $1 / 10(\mathrm{v} / \mathrm{v})$ and $50 \mu \mathrm{L}$ were deposed onto a 20-well pre-coated CometSlide ${ }^{\mathrm{TM}}$. The agarose was allowed to solidify by placing the slides flat at $4{ }^{\circ} \mathrm{C}$ in the dark for $15 \mathrm{~min}$. The slides were then immersed in a pre-chilled lysis solution (Trevigen \# 4250-050-01) for $1 \mathrm{~h}$ at $4{ }^{\circ} \mathrm{C}$ to remove the membrane, cellular proteins and histones. Following lysis, DNA unwinding was completed by incubating the slides in a freshly prepared alkaline unwinding solution $(200 \mathrm{mM} \mathrm{NaOH}, 1 \mathrm{mM}$ EDTA $\mathrm{pH}>13$ ) for $1 \mathrm{~h}$ at room temperature. The slides were then subjected to electrophoresis at $21 \mathrm{~V}$ for $30 \mathrm{~min}$ at $4{ }^{\circ} \mathrm{C}$ in the same alkaline solution, washed twice with $\mathrm{dH}_{2} \mathrm{O}$ for 5 min each, washed in $70 \%$ ethanol for $5 \mathrm{~min}$, dried at $37{ }^{\circ} \mathrm{C}$ for $30 \mathrm{~min}$, and stained with $50 \mu \mathrm{L}$ of diluted SYBR Green solution (1/10,000 in TE buffer $\mathrm{pH} 7.5$, Trevigen \# 4250-050-05). The slides were allowed to dry completely at room temperature before observation under the epifluorescence microscope (Microvision instruments, Excitation/ Emission: $494 / 521 \mathrm{~nm}, 20 X$ zoom). Images of 100 randomly selected non-overlapping cells were captured and analyzed using Tritek CometScore software. A variety of measurements including the percentage of DNA in the tail (expressed as \% of total DNA), the tail length (measured from the leading edge of the comet head) and tail moment (the measure of tail length multiplied by tail intensity) were calculated to evaluate the extent of DNA damage. Mean values from at least 100 nuclei were used in calculations. All steps were conducted in the dark to minimize extraneous sources of DNA damage.

\subsection{Myogenic differentiation and myotubes quantification}

Myoblasts from normal and FSHD primary cell lines were seeded at a density of $3.10^{5}$ cells per $10 \mathrm{~cm}$ collagen-coated petri dishes, and cultured in $10 \mathrm{~mL}$ of proliferation medium supplemented with $100 \mu \mathrm{M}$ of tempol, $1 \mathrm{mM} \mathrm{N}$-Acetyl-L-cysteine (NAC) (Sigma \#A7250) or DMSO (control). $48 \mathrm{~h}$ later the cells were collected, washed and seeded in $35 \mathrm{~mm}$ collagen-coated petri dishes (80-100\% confluence) under proliferation conditions. Myogenic differentiation was then induced $4 \mathrm{~h}$ later by replacing the growth medium with differentiation medium, supplemented or not with $100 \mu \mathrm{M}$ tempol or $1 \mathrm{mM}$ NAC. The differentiation medium was replaced every $72 \mathrm{~h}$ to ensure a constant antioxidant concentration. The cells were kept 6 days under differentiation conditions and were then fixed and immuno-stained with anti-Troponin $\mathrm{T}$ primary antibody, as described previously. The diameter of atrophic myotubes was measured using Imagej software. For each myotube the mean value of three diameter measurements at three different points was calculated in $\mu \mathrm{m}$. At least 100 myotubes were counted per condition.

\subsection{Transcriptome profiling}

RNA was prepared using organic extraction and ethanol precipitation as described [60] followed by silica column cleanup using Nucleospin RNA Extraction kit (Macherey Nagel). RNA extracted from pMyo isolated from 6 FSHD patients and 5 healthy individuals (biological replicates) was Cy3-labeled, mixed with a pool of RNA samples labeled with Cy5 and hybridized to Gene
Expression microarrays ( $4 \times 44 \mathrm{k} \# \mathrm{G} 4112 \mathrm{~F}$, Agilent) and scanned as instructed by the manufacturer. Scanned images were then analyzed using the Feature Extraction software (Agilent) and the gene expression data were treated in $\mathrm{R}$ and Bioconductor. Spots with intensity lower than 50 or lower than background in more than $50 \%$ of biological replicates have been removed from further analysis. The background correction and intensity normalization procedures were applied for the remaining $\sim 30000$ probes using the Bioconductor package vsn [61]. A background offset and a scaling factor for each array and dye channel were calculated using the least squares regression procedure, then a generalized logtransformation was applied. To determine the differentially expressed genes, a $t$-test analysis was applied using the limma package from Bioconductor [61]. Using this package, a linear model is fitted to the expression data for each gene. An empirical Bayes moderation of the standard errors was performed. This analysis resulted in the identification of 512 and 94 significant Agilent ID in FSHD myoblasts and myotubes respectively. Gene symbols and descriptions corresponding to significant Agilent IDs were retrieved from the Agilent microarray annotation file and $\mathrm{db} 2 \mathrm{db}$ and DAVID gene ID conversion tools. In case of disagreement between the sources, HGNC database (http://www.genenames.org/) was consulted. In total, 504 and 141 unique genes were differentially expressed in FSHD myoblasts and myotubes respectively; 400 and 109 genes were protein-coding.

\subsection{Functional annotation of differentially expressed genes}

Protein-coding genes differentially expressed in FSHD myoblasts and myotubes were used for functional annotation with DAVID (http://david.abcc.ncifcrf.gov/) using GOTERM_BP_FAT list and the default background. The stringency of functional annotation clustering was set to "medium". To establish a reliable threshold of significant functional clusters, we generated random lists of 266, 75, 52 and 27 genes corresponding to the number of genes up- and downregulated in FSHD myoblasts and myotubes, functionally annotated them with DAVID and used the most significant p-values and FDRs as thresholds. Significant functional clusters were then manually assembled into superclusters using Microsoft Excel with Ablebits add-ons (https://www.ablebits.com/ ) .

\subsection{Statistical analysis}

Tail moment data for Comet assay have been compared using single-factor ANOVA incorporating 75th percentile as a characteristic of a tail moment distribution according to recommendation in [62]. Mann-Whitney test was performed using $\mathrm{R}$ function wilcox.test. Student's $t$-test was performed using Excel function $T$ TEST, a p-value of 0.05 was considered statistically significant. Statistical power was calculated using http://powerandsamplesize.com/. Kruskal-Wallis test on Tail moment distributions was performed using kruskal.test function in R. The number of experiments and samples on which statistical analysis were performed are indicated in each experiment.

\subsection{3. $R T-P C R$}

RNA was prepared using organic extraction and ethanol precipitation as described [60]. Reverse transcription and PCR amplification of DUX4 were carried out as described in detail previously [38].

\subsection{Microarray validation}

Total RNA was isolated from $2 \times 10^{6}$ myoblasts, or myotubes using 
Trizol (Invitrogen) and reverse transcribed using the High Capacity cDNA Archive kit (Applied Biosystems) according to the manufacturer protocol, mixed with 2x Taqman PCR mix (Applied Biosystems) and analyzed via qPCR on Abiprism 7900HT using Taqman Low Density Array (TLDA) (Applied Biosystems) charged with the following probes: BLM, Hs00172060_m1; CCNB1, Hs01030101_g1; CDC25C, Hs00156407_m1; E2F1, Hs00153451_m1; KIF20A, Hs00993573_m1; MPP4, Hs00608861_m1; PLK1, Hs00983227_m1; RNASEH2A, Hs00197370_m1; RRM2, Hs00357247_g1; TRAIP, Hs00183394_m1; CCNA, Hs00996789_g1; TRIM43, Hs00299174_m1; PRAMEF2, Hs00363780_m1; MBD3L2, Hs00544743_m1. Expression was analyzed using $\Delta \Delta$ Ct method using GAPDH, Hs03929097_g1.

\section{Conflict of interest}

The authors declare no conflict of interest.

\section{Acknowledgments}

This research was supported by the MEGAFSHD grant from the Association Française contre les Myopathies (AFM) to YSV and the Grant no. 16-54-16015 from the Russian Foundation for Basic Research to VZ. We thank Dr. Dalila Laoudj-Chenivesse for primary myoblasts and Ms. Shirmoné Botha for critical reading of the manuscript.

\section{References}

[1] J.C. Deenen, H. Arnts, S.M. van der Maarel, G.W. Padberg, J.J. Verschuuren, E. Bakker, S.S. Weinreich, A.L. Verbeek, B.G. van Engelen, Population-based incidence and prevalence of facioscapulohumeral dystrophy, Neurology 83 (12) (2014) 1056-1059.

[2] M. Richards, F. Coppee, N. Thomas, A. Belayew, M. Upadhyaya, Facioscapulohumeral muscular dystrophy (FSHD): an enigma unravelled? Hum. Genet 131 (3) (2012) 325-340.

[3] D.S. Cabianca, D. Gabellini, The cell biology of disease: FSHD: copy number variations on the theme of muscular dystrophy, J. Cell Biol. 191 (6) (2010) 1049-1060.

[4] M. Bakay, Z. Wang, G. Melcon, L. Schiltz, J. Xuan, P. Zhao, V. Sartorelli, J. Seo, E. Pegoraro, C. Angelini, B. Shneiderman, D. Escolar, Y.W. Chen, S.T. Winokur, L M. Pachman, C. Fan, R. Mandler, Y. Nevo, E. Gordon, Y. Zhu, Y. Dong, Y. Wang, E. P. Hoffman, Nuclear envelope dystrophies show a transcriptional fingerprint suggesting disruption of Rb-MyoD pathways in muscle regeneration, Brain 129 (Pt 4) (2006) 996-1013.

[5] B. Celegato, D. Capitanio, M. Pescatori, C. Romualdi, B. Pacchioni, S. Cagnin, A. Vigano, L. Colantoni, S. Begum, E. Ricci, R. Wait, G. Lanfranchi, C. Gelfi, Parallel protein and transcript profiles of FSHD patient muscles correlate to the D4Z4 arrangement and reveal a common impairment of slow to fast fibre differentiation and a general deregulation of MyoD-dependent genes, Proteomics 6 (19) (2006) 5303-5321.

[6] P.G. van Overveld, R.J. Lemmers, L.A. Sandkuijl, L. Enthoven, S.T. Winokur, F. Bakels, G.W. Padberg, G.J. van Ommen, R.R. Frants, S.M. van der Maarel, Hypomethylation of D4Z4 in 4q-linked and non-4q-linked facioscapulohumeral muscular dystrophy, Nat. Genet. 35 (4) (2003) 315-317.

[7] S.T. Winokur, Y.W. Chen, P.S. Masny, J.H. Martin, J.T. Ehmsen, S.J. Tapscott, S. M. van der Maarel, Y. Hayashi, K.M. Flanigan, Expression profiling of FSHD muscle supports a defect in specific stages of myogenic differentiation, Hum. Mol. Genet. 12 (22) (2003) 2895-2907.

[8] D. Laoudj-Chenivesse, G. Carnac, C. Bisbal, G. Hugon, S. Bouillot, C. Desnuelle, Y. Vassetzky, A. Fernandez, Increased levels of adenine nucleotide translocator 1 protein and response to oxidative stress are early events in facioscapulohumeral muscular dystrophy muscle, J. Mol. Med. 83 (3) (2005) 216-224.

[9] R.J. Osborne, S. Welle, S.L. Venance, C.A. Thornton, R. Tawil, Expression profile of FSHD supports a link between retinal vasculopathy and muscular dystrophy, Neurology 68 (8) (2007) 569-577.

[10] P. Arashiro, I. Eisenberg, A.T. Kho, A.M. Cerqueira, M. Canovas, H.C. Silva, R. C. Pavanello, S. Verjovski-Almeida, L.M. Kunkel, M. Zatz, Transcriptional regulation differs in affected facioscapulohumeral muscular dystrophy patients compared to asymptomatic related carriers, Proc. Natl. Acad. Sci. USA 106 (15) (2009) 6220-6225.

[11] S. Cheli, S. Francois, B. Bodega, F. Ferrari, E. Tenedini, E. Roncaglia, S. Ferrari, E. Ginelli, R. Meneveri, Expression profiling of FSHD-1 and FSHD-2 cells during myogenic differentiation evidences common and distinctive gene dysregulation patterns, PloS One 6 (6) (2011) e20966.

[12] K. Tsumagari, S.C. Chang, M. Lacey, C. Baribault, S.V. Chittur, J. Sowden, R. Tawil, G.E. Crawford, M. Ehrlich, Gene expression during normal and FSHD myogenesis, BMC Med. Genom. 4 (2011) 67.

[13] F. Rahimov, O.D. King, D.G. Leung, G.M. Bibat, C.P. Emerson Jr., L.M. Kunkel, K. R. Wagner, Transcriptional profiling in facioscapulohumeral muscular dystrophy to identify candidate biomarkers, Proc. Natl. Acad. Sci. USA 109 (40) (2012) 16234-16239.

[14] G. Tasca, M. Pescatori, M. Monforte, M. Mirabella, E. Iannaccone, R. Frusciante, T. Cubeddu, F. Laschena, P. Ottaviani, E. Ricci, Different molecular signatures in magnetic resonance imaging-staged facioscapulohumeral muscular dystrophy muscles, PloS One 7 (6) (2012) e38779.

[15] A. Tassin, B. Leroy, D. Laoudj-Chenivesse, A. Wauters, C. Vanderplanck, M.C. Le Bihan, F. Coppee, R. Wattiez, A. Belayew, FSHD myotubes with different phenotypes exhibit distinct proteomes, PloS One 7 (12) (2012) e51865.

[16] P. Dmitriev, U. Kairov, T. Robert, A. Barat, V. Lazar, G. Carnac, D. Laoudj-Chenivesse, Y.S. Vassetzky, Cancer-related genes in the transcription signature of facioscapulohumeral dystrophy myoblasts and myotubes, J. Cell Mol. MEd 18 (2) (2014) 208-217.

[17] P. Dmitriev, L. Stankevicins, E. Ansseau, A. Petrov, A. Barat, P. Dessen, T. Robert, A. Turki, V. Lazar, E. Labourer, A. Belayew, G. Carnac, D. Laoudj-Chenivesse, M. Lipinski, Y.S. Vassetzky, Defective regulation of microRNA target genes in myoblasts from facioscapulohumeral dystrophy patients, J. Biol. Chem. 288 (49) (2013) 34989-35002.

[18] C. Dib, Y.B. Saada, P. Dmitriev, C. Richon, P. Dessen, D. Laoudj-Chenivesse, G. Carnac, M. Lipinski, Y.S. Vassetzky, Correction of the FSHD Myoblast Differentiation Defect by Fusion With Healthy Myoblasts, J Cell Physiol (2015).

[19] M. Barro, G. Carnac, S. Flavier, J. Mercier, Y. Vassetzky, D. Laoudj-Chenivesse, Myoblasts from affected and non-affected FSHD muscles exhibit morphological differentiation defects, J. Cell Mol. Med. 14 (1-2) (2010) 275-289.

[20] S.T. Winokur, K. Barrett, J.H. Martin, J.R. Forrester, M. Simon, R. Tawil, S. A. Chung, P.S. Masny, D.A. Figlewicz, Facioscapulohumeral muscular dystrophy (FSHD) myoblasts demonstrate increased susceptibility to oxidative stress, Neuromuscul. Disord. 13 (4) (2003) 322-333.

[21] V. Sharma, N. Harafuji, A. Belayew, Y.W. Chen, DUX4 differentially regulates transcriptomes of human rhabdomyosarcoma and mouse C2C12 cells, PloS One 8 (5) (2013) e64691.

[22] A. Turki, M. Hayot, G. Carnac, F. Pillard, E. Passerieux, S. Bommart, E. Raynaud de Mauverger, G. Hugon, J. Pincemail, S. Pietri, K. Lambert, A. Belayew, Y. Vassetzky, R. Juntas Morales, J. Mercier, D. Laoudj-Chenivesse, Functional muscle impairment in facioscapulohumeral muscular dystrophy is correlated with oxidative stress and mitochondrial dysfunction, Free Radic. Biol. Med 53 (553) (2012) 1068-1079.

[23] A. Musaro, S. Fulle, G. Fano, Oxidative stress and muscle homeostasis, Curr. Opin. Clin. Nutr. Metab. Care 13 (3) (2010) 236-242.

[24] E. Barbieri, P. Sestili, Reactive oxygen species in skeletal muscle signaling, J. Signal. Transduct. 2012 (2012) 982794.

[25] E. Marzetti, J.C. Hwang, H.A. Lees, S.E. Wohlgemuth, E.E. Dupont-Versteegden, C.S. Carter, R. Bernabei, C. Leeuwenburgh, Mitochondrial death effectors: relevance to sarcopenia and disuse muscle atrophy, Biochim. Biophys. Acta 1800 (3) (2010) 235-244.

[26] M. Bar-Shai, E. Carmeli, A.Z. Reznick, The role of NF-kappa B in protein breakdown in immobilization, aging, and exercise: from basic processes to promotion of health, Ann. NY Acad. Sci. 1057 (2005) 431-447.

[27] D. Bosnakovski, Z. Xu, E.J. Gang, C.L. Galindo, M. Liu, T. Simsek, H.R. Garner, S. Agha-Mohammadi, A. Tassin, F. Coppee, A. Belayew, R.R. Perlingeiro, M. Kyba, An isogenetic myoblast expression screen identifies DUX4-mediated FSHD-associated molecular pathologies, EMBO J. 27 (20) (2008) 2766-2779.

[28] S.P. Jackson, J. Bartek, The DNA-damage response in human biology and disease, Nature 461 (7267) (2009) 1071-1078.

[29] M. O'Driscoll, Diseases associated with defective responses to DNA damage, Cold Spring Harb. Perspect. Biol. 4 (12) (2012).

[30] W.M. Schmidt, M.H. Uddin, S. Dysek, K. Moser-Thier, C. Pirker, H. Hoger, I. M. Ambros, P.F. Ambros, W. Berger, R.E. Bittner, DNA damage, somatic aneuploidy, and malignant sarcoma susceptibility in muscular dystrophies, PLoS Genet. 7 (4) (2011) e1002042.

[31] A. Fanzani, E. Monti, R. Donato, G. Sorci, Muscular dystrophies share pathogenetic mechanisms with muscle sarcomas, Trends Mol. MEd 19 (9) (2013) 546-554.

[32] N.P. Singh, M.T. McCoy, R.R. Tice, E.L. Schneider, A simple technique for quantitation of low levels of DNA damage in individual cells, Exp. Cell Res. 175 (1) (1988) 184-191.

[33] R.R. Tice, P.W. Andrews, N.P. Singh, The single cell gel assay: a sensitive technique for evaluating intercellular differences in DNA damage and repair, Basic Life Sci. 53 (1990) 291-301.

[34] R.R. Tice, E. Agurell, D. Anderson, B. Burlinson, A. Hartmann, H. Kobayashi, Y. Miyamae, E. Rojas, J.C. Ryu, Y.F. Sasaki, Single cell gel/comet assay: 
guidelines for in vitro and in vivo genetic toxicology testing, Environ. Mol. Mutagen 35 (3) (2000) 206-221.

[35] J.T. Vilquin, J.P. Marolleau, S. Sacconi, I. Garcin, M.N. Lacassagne, I. Robert, B. Ternaux, B. Bouazza, J. Larghero, C. Desnuelle, Normal growth and regenerating ability of myoblasts from unaffected muscles of facioscapulohumeral muscular dystrophy patients, Gene Ther. 12 (22) (2005) 1651-1662.

[36] R. Morosetti, M. Mirabella, C. Gliubizzi, A. Broccolini, C. Sancricca, M. Pescatori, T. Gidaro, G. Tasca, R. Frusciante, P.A. Tonali, G. Cossu, E. Ricci, Isolation and characterization of mesoangioblasts from facioscapulohumeral muscular dystrophy muscle biopsies, Stem Cells 25 (12) (2007) 3173-3182.

[37] R. Morosetti, T. Gidaro, A. Broccolini, C. Gliubizzi, C. Sancricca, P.A. Tonali, E. Ricci, M. Mirabella, Mesoangioblasts from facioscapulohumeral muscular dystrophy display in vivo a variable myogenic ability predictable by their in vitro behavior, Cell Transplant. 20 (8) (2011) 1299-1313.

[38] C. Vanderplanck, E. Ansseau, S. Charron, N. Stricwant, A. Tassin, D. LaoudjChenivesse, S.D. Wilton, F. Coppee, A. Belayew, The FSHD atrophic myotube phenotype is caused by DUX4 expression, PloS One 6 (10) (2011) e26820.

[39] V. Kowaljow, A. Marcowycz, E. Ansseau, C.B. Conde, S. Sauvage, C. Matteotti, C. Arias, E.D. Corona, N.G. Nunez, O. Leo, R. Wattiez, D. Figlewicz, D. LaoudjChenivesse, A. Belayew, F. Coppee, A.L. Rosa, The DUX4 gene at the FSHD1A locus encodes a pro-apoptotic protein, Neuromuscul. Disord. 17 (8) (2007) $611-623$.

[40] L.M. Wallace, S.E. Garwick, W. Mei, A. Belayew, F. Coppee, K.J. Ladner, D. Guttridge, J. Yang, S.Q. Harper, DUX4, a candidate gene for facioscapulohumeral muscular dystrophy, causes p53-dependent myopathy in vivo, Ann. Neurol. 69 (3) (2011) 540-552.

[41] R.D. Wuebbles, S.W. Long, M.L. Hanel, P.L. Jones, Testing the effects of FSHD candidate gene expression in vertebrate muscle development, Int J. Clin. Exp. Pathol. 3 (4) (2010) 386-400.

[42] A. Carre, R.A. Louzada, R.S. Fortunato, R. Ameziane-El-Hassani, S. Morand, V. Ogryzko, D.P. de Carvalho, H. Grasberger, T.L. Leto, C. Dupuy, When an Intramolecular Disulfide Bridge Governs the Interaction of DUOX2 with Its Partner DUOXA2, Antioxid. Redox Signal. 23 (9) (2015) 724-733.

[43] Y. Morel, R. Barouki, Repression of gene expression by oxidative stress, Biochem J. 342 (Pt 3) (1999) 481-496.

[44] M. Zafarullah, W.Q. Li, J. Sylvester, M. Ahmad, Molecular mechanisms of N-acetylcysteine actions, Cell Mol. Life Sci. 60 (1) (2003) 6-20.

[45] K. Arahata, T. Ishihara, H. Fukunaga, S. Orimo, J.H. Lee, K. Goto, I. Nonaka, Inflammatory response in facioscapulohumeral muscular dystrophy (FSHD): immunocytochemical and genetic analyses, Muscle Nerve Suppl. (2) (1995) S56-S66.

[46] A. Pakula, J. Schneider, J. Janke, U. Zacharias, H. Schulz, N. Hubner, A. Mahler, A. Spuler, S. Spuler, P. Carlier, M. Boschmann, Altered expression of cyclin A 1 in muscle of patients with facioscapulohumeral muscle dystrophy (FSHD-1), PloS One 8 (9) (2013) e73573.
[47] D.M. DeMarini, Genotoxicity of tobacco smoke and tobacco smoke condensate: a review, Mutat. Res 567 (2-3) (2004) 447-474.

[48] R.P. Rastogi, Richa, A. Kumar, M.B. Tyagi, R.P. Sinha, Molecular mechanisms of ultraviolet radiation-induced DNA damage and repair, J. Nucleic Acids 2010 (2010) 592980.

[49] R. De Bont, N. van Larebeke, Endogenous DNA damage in humans: a review of quantitative data, Mutagenesis 19 (3) (2004) 169-185.

[50] A. Mazouzi, G. Velimezi, J.I. Loizou, DNA replication stress: causes, resolution and disease, Exp. Cell Res 329 (1) (2014) 85-93.

[51] S. Yan, M. Sorrell, Z. Berman, Functional interplay between ATM/ATR-mediated DNA damage response and DNA repair pathways in oxidative stress, Cell Mol. Life Sci. 71 (20) (2014) 3951-3967.

[52] J. Nakamura, D.K. La, J.A. Swenberg, 5'-nicked apurinic/apyrimidinic sites are resistant to beta-elimination by beta-polymerase and are persistent in human cultured cells after oxidative stress, J. Biol. Chem. 275 (858) (2000) 5323-5328.

[53] M. Dizdaroglu, P. Jaruga, M. Birincioglu, H. Rodriguez, Free radical-induced damage to DNA: mechanisms and measurement, Free Radic. Biol. Med. 32 (11) (2002) 1102-1115.

[54] M. Simonatto, L. Latella, P.L. Puri, DNA damage and cellular differentiation: more questions than responses, J. Cell Physiol. 213 (3) (2007) 642-648.

[55] P.L. Puri, K. Bhakta, L.D. Wood, A. Costanzo, J. Zhu, J.Y. Wang, A myogenic differentiation checkpoint activated by genotoxic stress, Nat. Genet 32 (4) (2002) 585-593.

[56] R. de Senzi Moraes Pinto, R. Ferretti, L.H. Moraes, H.S. Neto, M.J. Marques, E. Minatel, N-acetylcysteine treatment reduces TNF-alpha levels and myonecrosis in diaphragm muscle of mdx mice, Clin. Nutr. 32 (3) (2013) 472-475.

[57] J.R. Terrill, H.G. Radley-Crabb, M.D. Grounds, P.G. Arthur, N-Acetylcysteine treatment of dystrophic mdx mice results in protein thiol modifications and inhibition of exercise induced myofibre necrosis, Neuromuscul. Disord. 22 (5) (2012) 427-434

[58] I.M. Ward, J. Chen, Histone H2AX is phosphorylated in an ATR-dependent manner in response to replicational stress, J. Biol. Chem. 276 (51) (2001) 47759-47762.

[59] K. Malathi, Y. Xiao, A.P. Mitchell, Catalytic roles of yeast GSK3beta/shaggy homolog Rim11p in meiotic activation, Genetics 153 (3) (1999) 1145-1152.

[60] P. Chomczynski, N. Sacchi, The single-step method of RNA isolation by acid guanidinium thiocyanate-phenol-chloroform extraction: twenty-something years on, Nat. Protoc. 1 (2) (2006) 581-585.

[61] G. Smyth, Limma: linear models for microarray data, in: V.C.R. Gentleman, S. Dudoit, W. Hubert (Eds.), Bioinformatics and Computational Biology Solutions unsing R and Bioconductor, Springer, New York, 2005, pp. 397-420.

[62] S.J. Wiklund, E. Agurell, Aspects of design and statistical analysis in the Comet assay, Mutagenesis 18 (2) (2003) 167-175. 